\title{
Hypoxia-Induced Developmental Delays of Inhibitory Interneurons Are Reversed by Environmental Enrichment in the Postnatal Mouse Forebrain
}

\author{
Mila Komitova, ${ }^{1}$ Dionysios Xenos, ${ }^{1 *}$ Natalina Salmaso, ${ }^{1 \star}$ Kathy May Tran, ${ }^{1}$ Theresa Brand, ${ }^{1}$ Michael L. Schwartz, ${ }^{2}$ \\ Laura Ment, ${ }^{3}$ and Flora M. Vaccarino ${ }^{1,2}$ \\ ${ }^{1}$ Child Study Center, ${ }^{2}$ Department of Neurobiology, and ${ }^{3}$ Department of Pediatrics, Yale University School of Medicine, New Haven, Connecticut 06520
}

\begin{abstract}
Infants born premature experience hypoxic episodes due to immaturity of their respiratory and central nervous systems. This profoundly affects brain development and results in cognitive impairments. We used a mouse model to examine the impact of hypoxic rearing $\left(9.5-10.5 \% \mathrm{O}_{2}\right)$ from postnatal day 3 to 11 (P3-P11) on GABAergic interneurons and the potential for environmental enrichment to ameliorate these developmental abnormalities. At P15 the numbers of cortical interneurons expressing immunohistochemically detectable levels of parvalbumin (PV), somatostatin (SST), and vasoactive intestinal peptide were decreased in hypoxic-reared mice by $59 \%$, $32 \%$, and $38 \%$, respectively, compared with normoxic controls. Hypoxia also decreased total GABA content in frontal neocortex by $31 \%$. However, GAD67-EGFP knock-in mice reared under hypoxic conditions showed no changes in total number of GAD67-EGFP ${ }^{+}$cells and no evidence of increased interneuron death, suggesting that the total number of interneurons was not decreased, but rather, that hypoxic-rearing decreased interneuron marker expression in these cells. In adulthood, PV and SST expression levels were decreased in hypoxic-reared mice. In contrast, intensity of reelin (RLN) expression was significantly increased in adult hypoxic-reared mice compared with normoxic controls. Housing mice in an enriched environment from P21 until adulthood normalized phenotypic interneuron marker expression without affecting total interneuron numbers or leading to increased neurogenesis. Our data show that (1) hypoxia decreases PV and SST and increases RLN expression in cortical interneurons during postnatal cortical development and (2) enriched environment has the capacity to normalize the interneuron abnormalities in cortex.
\end{abstract}

\section{Introduction}

The effects of premature birth on the developing brain are not well understood. Commonly used models of perinatal brain injury based on hypoxia-ischemia cause focal infarct damage that mimics only the most extreme cases of intraventricular hemorrhage and porencephalic lesions (for review, see Scafidi et al., 2009). To recapitulate the forebrain volume loss, enlargement of ventricles and gradual structural and functional improvement that are seen in the great majority of preterm children, we developed a rodent model of chronic early postnatal hypoxia

\footnotetext{
Received Nov. 13, 2012; revised June 14, 2013; accepted July 8, 2013.

Author contributions: M.K., L.M., and F.V. designed research; M.K., D.X., N.S., K.M.T., T.B., and M.L.S. performed research; M.K., D.X., N.S., K.M.T., and F.V. analyzed data; M.K. and F.V. wrote the paper.

This work was supported by P01 NS062686-04 and R01 NS060750 from the National Institute of Neurological Disorders and Stroke. M.K. was supported by a fellowship from the Swedish Brain Foundation (Hjarnfonden) and N.S. by a fellowship from the Fonds de Recherche en Sante du Quebec (2009-2012) and the Canadian Institute of Health Research (2012-present). We thank Drs. Charles Stiles and John Alberta at Dana Farber Cancer Institute, Boston, for their gift of Olig2 antibody and Dr. Kazuaki Yoshikawa at Osaka University, Japan, for his gift of Dlx-2 antibody. We thank Dr. Hanna Stevens and Dr. Karen Muller-Smith for useful discussions. Dr. George Anderson, Yale Child Study Center, is greatly acknowledged for technical advice about HPLC. We acknowledge Dr. Simone Tomasi, Elise Cheng, Suzannah Luft, Devon Fagel, and Dr. Teresa Sandoval-Minero for useful discussions and technical help. The authors declare no competing financial interests.

*D.X. and N.S. contributed equally to this work.

Correspondence should be addressed to Flora Vaccarino, Child Study Center, 230 South Frontage Road, New Haven, CT 06520. E-mail: flora.vaccarino@yale.edu.

DOI:10.1523/JNEUROSCI.5286-12.2013

Copyright $\odot 2013$ the authors $\quad 0270-6474 / 13 / 3313375-13 \$ 15.00 / 0$
}

(Schwartz et al., 2004; Fagel et al., 2006). Mice subjected to chronic postnatal hypoxia suffer acute decreases of the total numbers of excitatory neurons in the cerebral cortex, followed by a recovery in excitatory neuron numbers $\sim 1$ month after the insult, in part through increased neurogenesis from glial fibrillary acidic protein (GFAP)-expressing neural stem cells (Bi et al., 2011); in contrast, inhibitory interneuron subtypes that are immunoreactive for the calcium-binding protein parvalbumin $(\mathrm{PV})$ or calretinin (CR) remain chronically decreased (Fagel et al., 2006, 2009). Thus, interneuron loss could be responsible in part for the persistent behavioral impairments in spatial and working memory in this model (Li et al., 2009).

In this study, we characterized the short- and long-term effects of hypoxia on interneurons in the cerebral cortex and explored the mechanisms of the hypoxia-induced perturbations. Interneurons were phenotyped with markers such as PV, somatostatin (SST), reelin (RLN), and vasoactive intestinal polypeptide (VIP), thus identifying virtually all cortical interneuron subtypes (Wonders and Anderson, 2006; Gelman and Marín, 2010; Rudy et al., 2011; Fig. 1D). Our data strongly suggest that hypoxic injury inhibits maturation of the neurochemical properties of $\mathrm{PV}^{+}, \mathrm{SST}^{+}$, and $\mathrm{RLN}^{+}$interneurons. To further investigate the ability of known therapeutic interventions to impact these changes in cortical interneurons, we compared mice reared in enriched environment to those reared in standard housing. Enriched environment is a powerful intervention paradigm that 
A

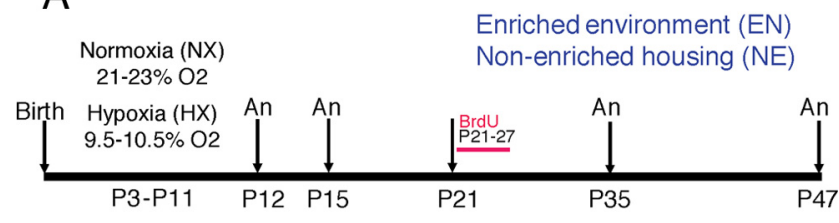

B

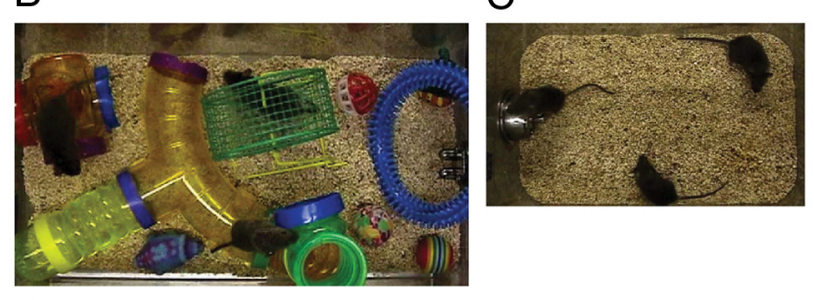

D

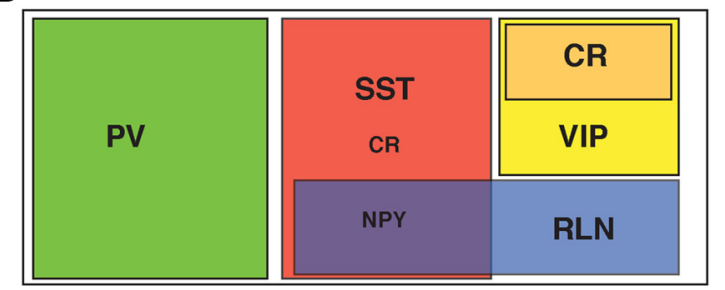

Figure 1. A, Experimental design of the study. Mice were housed in normoxic (NX) or hypoxic (HX) conditions from P3 to P11. Mice were perfused and analyzed (An) at P12, P15, P35, and $P 47$. Upon weaning at $P 21$, mice were either introduced into enriched environment $(E N ; B)$ or housed in standard, nonenriched (NE) conditions (C). An, time of analysis. $\boldsymbol{D}$, Schematic of the different interneuron subpopulations identified by the different markers used in the study (adapted from Gelman and Marín, 2010). NPY, neuropeptide Y.

has been shown to be beneficial during recovery from various brain lesions (Nithianantharajah and Hannan, 2006). Moreover, in a recent study we reported that post hypoxia environmental enrichment enhanced the generation of excitatory neurons in the hippocampal dentate gyrus and improved performance in hippocampal-mediated spatial memory (Salmaso et al., 2012). Interestingly, in the current study, we found that enriched environment is able to reverse virtually all the GABAergic interneuron perturbations caused by hypoxia.

\section{Materials and Methods}

Rearing in hypoxia and enrichment. An experimental scheme of the study is depicted in Figure $1 A$. There were four experimental groups: normoxia reared in standard laboratory conditions, i.e., nonenriched environment (NX-NE); hypoxia reared in standard environment (HX-NE); normoxia reared in enriched environment (NX-EN); and hypoxia reared in enriched environment (HX-EN). Dams and litters in the hypoxic conditions were housed in standard laboratory cages placed inside a specially constructed airtight Plexiglas chamber with a continuous flow of air with $\mathrm{O}_{2}$ displaced by $\mathrm{N}_{2}$ to reach an overall concentration of $\mathrm{O}_{2}$ in the chamber of $9.5-10.5 \%$. Oxygen levels were monitored from minute to minute by sensors coupled to a computer. The period of hypoxia began at postnatal day 3 (P3) and continued for $8 \mathrm{~d}$ until P11. Hypoxic chambers were inspected twice daily to ensure appropriate oxygen levels.

The enriched environment period began at P21, day of weaning, and continued until P35 or P47. After weaning and gender separation, no more than eight pups were housed per cage. Mice in the enriched environment were housed in large Plexiglas cages measuring $24 \mathrm{~cm} \mathrm{~W} \times 20$ $\mathrm{cm} \mathrm{H} \times 46 \mathrm{~cm} \mathrm{~L}$ (Fig. 1B). A running wheel; a series of clear and colored plastic "habit-trails" of different configurations; and several small plastic, or hard rubber, or wooden balls and objects of different shapes were scattered on the cage floor. Additionally, metal link chains or small wooden blocks were suspended from the cage roof. Every $3 \mathrm{~d}$, enrich- ment cage objects were changed, cleaned, disinfected, and rearranged to ensure novelty. After weaning, mice in the nonenriched environment groups were housed two to three per cage in standard rack mount Plexiglas cages measuring $18 \mathrm{~cm} \mathrm{~W} \times 13 \mathrm{~cm} \mathrm{H} \times 29 \mathrm{~cm} \mathrm{~L}$ (Fig. 1C). The bottoms of all enriched and non enriched cages were lined with corncob bedding. All mice were exposed to a $12 \mathrm{~h} \mathrm{light/dark} \mathrm{cycle} \mathrm{and} \mathrm{were} \mathrm{pro-}$ vided with water and food ad libitum. For 1 week after weaning, food was provided in moistened form on the cage floor in addition to the regular wire bar cage top food hopper. Cages were changed weekly. All procedures were approved by the Yale Animal Resources Center and Institutional Animal Care and Use Committee.

Knock-in and transgenic mice. All mice used in this study were backcrossed to C57BL/6J mice for at least 10 generations. We used GAD67EGFP knock-in mice, carrying the enhanced green fluorescent protein (EGFP) gene in the endogenous Gad1 locus, which encodes the GABA synthetic enzyme glutamate decarboxylase isoform 67 (GAD67; Tamamaki et al., 2003). In this line, virtually all inhibitory GABA interneurons are fully labeled with EGFP from embryogenesis onward. The GFAP$\mathrm{CreER}^{\mathrm{T} 2}$ (GCE) mice were generated as previously described (Ganat et al., 2006). In these mice, the Cre recombinase-estrogen receptor type 2 fusion protein $\left(\mathrm{CreER}^{\mathrm{T} 2}\right)$ is expressed under the control of the human GFAP promoter (Gf2 fragment) (Brenner et al., 1994). PCR for genotyping was performed using the following primers spanning parts of the GFAP promoter and the Cre gene (5-GCAACGAGTGATGAGGTTCG CAAG-3) (forward) and (5-TCCGCCGCATAACCAGTGAAACAG-3) (reverse).

GCE mice were bred with CAG-CAT-EGFP (Nakamura et al., 2006) or R26R LacZ Cre reporter mice (Soriano, 1999) to produce double transgenic mice in which reporter expression was inducible in GFAP lineage cells by tamoxifen treatment. The CAG-CAT-EGFP reporter mice were genotyped using primers to the EGFP gene (5-AAGTTCATCTGCACCA CCG-3) (forward) and (5-TGCTCAGGTAGTGGTTGTCG-3) (reverse). The R26R LacZ reporter mice were genotyped using the specific primers: (5-AAAGTCGCTCTGAGTTGTTAT-3), (5-GCGAAGAGTTT GTCCTCAACC-3), and (5'-GGAGCGGGAGAAATGGATATG-3').

The numbers of animals used in experiments ranged between three and six per group from at least two different litters for most experiments to avoid litter effects. Each group contained both male and female mice.

Tamoxifen administration. GCE;CAG-CAT-EGFP, or GCE;R26R mice were injected with tamoxifen to induce reporter expression in cells where the GFAP promoter was active. Tamoxifen, dissolved in sunflower seed oil, was administered daily $(60 \mathrm{mg} / \mathrm{kg})$ by intraperitoneal injections from P12 to P14. Fate mapping of reporter-positive GFAP-lineage cells was performed at P35 and at P47.

Thymidine analog administration. To study the effects of enriched environment on neurogenesis, mice from the four experimental groups were given the thymidine analog 5-bromo-2-deoxyuridine (BrdU; Roche), which labels proliferating cells in the S-phase of the cell cycle and their resulting progeny. The BrdU tracer was given as intraperitoneal injections ( $50 \mathrm{mg} / \mathrm{kg}$ body weight), spaced $12 \mathrm{~h}$ apart and starting on P21, upon weaning into enriched or nonenriched environment conditions, for $7 \mathrm{~d}$. Mice were perfused at P47.

HPLC. Normoxic and hypoxic-reared mice were instantly killed by cervical dislocation. Brains were quickly harvested and sectioned into 1 $\mathrm{mm}$ sections that were flash frozen until processing. Tissue punches were obtained of the hippocampus; striatum; and occipital, frontal, and parietal cortices using a $500 \mu \mathrm{m}$ diameter punch and the samples were weighed using a microbalance. Content of gamma-aminobutyric acid in the brain was determined after precolumn orthophthaldehyde-3mercaptopropionic acid (OPT-MPA) derivatization as previously described (Durkin et al., 1988) with the following modifications. Tissue samples were sonicated in 20 volumes (v/w) of homogenizing solution, separation was on $25 \times 0.46 \mathrm{~cm}$ Phenomenex Ultremex $5 \mu \mathrm{m} \mathrm{C}_{18} \mathrm{HPLC}$ column, and a Shimadzu 10Axl fluorometric detector was used. GABA was determined using an (unmodified) mobile phase of 50\% $0.20 \mathrm{M}$ sodium acetate, $\mathrm{pH} 3.8$, containing $100 \mathrm{mg} / \mathrm{L}$ sodium EDTA/50\% acetonitrile $(0.9 \mathrm{ml} / \mathrm{min})$ and determined with an intra-assay coefficient of variation of $3.1 \%$. GABA content was expressed as nanogram GABA per milligram wet tissue weight. 
Tissue processing. Mice were deeply anesthetized with an intraperitoneal injection of ketamine-xylazine and perfused transcardially with PBS followed by $4 \%$ paraformaldehyde (PFA). Brains were dissected from the skull, postfixed in the same fixative for $24 \mathrm{~h}$, and subsequently placed in a $30 \%$ sucrose solution for $24-48 \mathrm{~h}$ until equilibration whereafter the brains were frozen. They were then embedded in optimal cutting temperature compound. Serial sagittal $20 \mu \mathrm{m}$ sections were cut with a Leica CM1900 cryostat at $-20^{\circ} \mathrm{C}$. Sections were placed on SuperFrost plus glass slides and stored at $-80^{\circ} \mathrm{C}$ until processing. Alternatively, following postfixation brains were sectioned coronally at $50 \mu \mathrm{m}$ thickness with a Leica VT $1000 S$ vibratome at room temperature. Free-floating sections were stored at $+4^{\circ} \mathrm{C}$ in a $0.04 \%$ sodium azide $\left(\mathrm{NaN}_{3} / \mathrm{PBS}\right)$ solution until subsequent staining.

Immunohistochemistry. Sections were washed in PBS and blocked for $1 \mathrm{~h}$ in $0.3 \%$ Triton-X in PBS containing 5\% normal goat serum. They were then incubated overnight in blocking solution containing primary antibodies at $+4^{\circ} \mathrm{C}$ and then washed three times with PBS. Afterward, sections were incubated for $1 \mathrm{~h}$ in secondary antibodies in blocking solution at room temperature. They were washed again in PBS, mounted where applicable, and coverslipped using Vectashield mounting medium containing DAPI where applicable (Vector Laboratories).

For BrdU and EGFP colabeling experiments, sequential staining was performed starting with labeling for EGFP with primary and secondary antibody, followed by fixation in $4 \%$ PFA for 15 min. Subsequently, sections were pretreated by incubating in $2 \mathrm{~N} \mathrm{HCl}$ for $40 \mathrm{~min}$ at $37^{\circ} \mathrm{C}$ to denature DNA to allow for BrdU detection, followed by several washes with PBS before incubating with primary anti-BrdU antibody followed by incubation in a fluorescently tagged secondary antibody.

For GABA or GAD67 colabeling with other markers, sequential staining was also performed, starting with GABA or GAD67 labeling with primary and secondary antibody without any detergent since this greatly diminished staining, followed by fixation in 4\% PFA for $15 \mathrm{~min}$ and staining for a second marker in blocking solution containing detergent. Use of detergent permeabilization has been reported to decrease the intensity of staining for GABA (Onteniente et al., 1986) and is not routinely used for GAD67 immunostaining; see, for example, Freichel et al. (2006). We confirmed that staining with anti-GAD67 while using detergent permeabilization resulted in much weaker stained cell bodies and strongly increased punctate labeling that tended to obscure the cell bodies, perhaps having to do with conformation change in epitope induced by detergent. The mild permeabilization achieved by freezing/thawing the tissue, as happens with staining of cryosections, was enough for a satisfactory staining with anti-GABA and anti-GAD67 antibodies.

The following primary antibodies were used for immunohistochemistry: chicken anti- $\beta$ galactosidase (1:1000; Abcam), rat anti-BrdU (1:250; Accurate Chemical), rabbit anti-activated caspase-3 (1:500; Cell Signaling Technology), guinea pig anti-Dlx-2 (1:9000; kindly provided by Dr. Kazuaki Yoshikawa, Osaka University, Japan), guinea pig anti-GABA (1:1000; Abcam), mouse anti-GAD67 (1:2000; Millipore), chicken anti-GFP (1:1000; Abcam), rabbit anti-Ki67 (1:500; Vector Laboratories), mouse anti-NeuN (1:100; Millipore), rabbit anti-Olig2 (1:20,000; kindly provided by Drs. Charles Stiles and John Alberta, Dana Farber Cancer Institute); rabbit anti-PV (1:500; SWANT), mouse anti-PV (1:500; Sigma), mouse anti-RLN (1:800; Millipore), rat anti-STT (1:200; Millipore), and rabbit anti-VIP (1: 800; Immunostar). The following secondary antibodies were used: species-specific goat Alexa Fluor 350, 488, and $594 \operatorname{IgG}$ (1:1000; Invitrogen) as well as DyLight 649-conjugated AffiniPure Donkey AntiRat IgG $(\mathrm{H}+\mathrm{L})$ and CY3-conjugated AffiniPure Donkey Anti-Mouse $\operatorname{IgG}(\mathrm{H}+\mathrm{L})$ (1:250; The Jackson Laboratory).

Stereological cell quantification. Cells labeled with the different markers were quantified in 6 serial sagittal or 12 serial coronal sections spanning the entire brain hemisphere in the sagittal or coronal plain, spaced 600 $\mu \mathrm{m}$ or $500 \mu \mathrm{m}$ apart, respectively. Cells were identified as positive for a marker if they expressed immunoreactivity visually deemed to be above background, even if it was very weak. This means that cells exhibiting varying levels of immunolabeling, from very weakly to very strongly stained, were all identified as marker positive. Unbiased stereological cell counting technique was applied using a Zeiss Axioskop 2 Mot Plus fluorescent microscope (Carl Zeiss) connected to a motorized stage con-
Table 1. Parameters for stereological cell counts in the cortex as well as the coefficient of error and the average cell count per sampling site for each marker and region

\begin{tabular}{|c|c|c|c|c|}
\hline & Counting frame & Sampling grid size & $\begin{array}{l}\text { Coefficient } \\
\text { of error } \\
\text { (Gundersen), } \\
m=1\end{array}$ & $\begin{array}{l}\text { Average cell } \\
\text { counts/sampling } \\
\text { site }\end{array}$ \\
\hline \multicolumn{5}{|l|}{ CTX } \\
\hline PV & $100 \times 100 \times 5 \mu \mathrm{m}$ & $700 \times 700 \mu \mathrm{m}$ & 0.14 & 0.47 \\
\hline RLN & $100 \times 100 \times 5 \mu \mathrm{m}$ & $700 \times 700 \mu \mathrm{m}$ & 0.16 & 0.64 \\
\hline SST & $100 \times 100 \times 5 \mu \mathrm{m}$ & $700 \times 700 \mu \mathrm{m}$ & 0.19 & 0.42 \\
\hline VIP & $100 \times 100 \times 5 \mu \mathrm{m}$ & $700 \times 700 \mu \mathrm{m}$ & 0.27 & 0.11 \\
\hline GAD67 EGFP & $100 \times 100 \times 5 \mu \mathrm{m}$ & $700 \times 700 \mu \mathrm{m}$ & 0.08 & 1.87 \\
\hline GABA & $100 \times 100 \times 5 \mu \mathrm{m}$ & $700 \times 700 \mu \mathrm{m}$ & 0.14 & 1.22 \\
\hline Dlx-2 & $100 \times 100 \times 5 \mu \mathrm{m}$ & $700 \times 700 \mu \mathrm{m}$ & 0.14 & 0.87 \\
\hline BrdU & $100 \times 100 \times 5 \mu \mathrm{m}$ & $700 \times 700 \mu \mathrm{m}$ & 0.17 & 0.30 \\
\hline Hp PV & $284 \times 182 \times 5 \mu \mathrm{m}$ & $452 \times 356 \mu \mathrm{m}$ & 0.14 & 0.67 \\
\hline
\end{tabular}

CTX, cortex; Hp, hippocampus.

trolled by StereoInvestigator software (MicroBrightfield) as previously described (Bi et al., 2011). Contours of the cerebral cortex (excluding the piriform and prelimbic cortices) and hippocampus (dentate gyrus and cornu ammonis) were delineated at 2.5 or $10 \times$ magnification using DAPI stain to delineate reference points. The StereoInvestigator software allowed for systematic and random sampling of cell counts using the optical fractionator method. Cells were counted at $40 \times$ magnification using a $3 \mathrm{D}$ counting frame in a sampling grid as specified in Table 1 . The coefficient of error (Gundersen), $m=1$, and the average cell count per sampling site are described for each marker and region in Table 1.

Quantification of intensity and distribution of expression of interneuron marker. Quantification of the intensity levels of immunolabeling with PV, RLN, and SST antibodies in individual cells was performed on images of RLN/SST and PV/RLN double immunostained brain sections from GAD67-EGFP normoxic and hypoxic-reared P47 mice. Serial images spanning $8 \mu \mathrm{m}$ in the $z$-plane were taken of the whole span of the primary motor (M1) and primary somatosensory cortex, hindlimb region (S1HL) $1.32 \mathrm{~mm}$ lateral to bregma with a $20 \times$ objective on a Zeiss Observer.Z1 microscope equipped with an ApoTome2. Exposure time was kept the same for all the images. A maximum projection image was created from each $z$-stack using Zeiss Axiovision 4.8 software.

Photo composites were created for each region aligning the images using Adobe Photoshop software, to represent the full extent of the cortex. DAPI nuclear labeling was used to determine cortical layer localization as upper cortical layers (L1-L4) or lower cortical layers (L5-L6). Interneurons were identified as GAD67-EGFP ${ }^{+}$cells. All interneurons expressing PV, SST, and RLN above background were numbered in the Adobe Photoshop software. The intensity of marker expression was determined using ImageJ $1.44 \mathrm{c} \mathrm{soft-}$ ware (National Institutes of Health). The intensity of immunolabeling corrected for background signal was determined using the following formula: Corrected Total Cell Fluorescence $=$ Integrated Density $-($ Area of selected cell $\times$ Mean fluorescence of background).

Statistical analysis. Statistical analyses were performed using StatView 4.51 and SPSS software. We used Student's $t$ test to test significance when only two groups were compared (normoxia vs hypoxia), two-way ANOVA when four groups were compared (normoxia vs hypoxia and standard vs enriched environment), or a factorial ANOVA for each PV, SST, and RLN immunolabeling intensity measurements in individual cells. Values were considered significant when $p<0.05$. Fisher's LSD post hoc analyses were conducted when $p$ values reached significance. Data are presented as mean \pm SEM.

\section{Results}

Long-lasting decrease in PV expression in the neocortex after hypoxia and normalization with environmental enrichment To examine the more immediate impact of hypoxia on inhibitory interneurons, we quantified the numbers of neurons exhibiting $\mathrm{PV}$ immunoreactivity $\left(\mathrm{PV}^{+}\right) 4 \mathrm{~d}$ after the exposure to chronic sub- 
lethal hypoxia between P3 and P11. In the neocortex of mice perfused at P15, hypoxia induced an over 2 -fold decrease in the number of interneurons that expressed immunohistochemically detectable levels of PV as compared with mice reared in room air (normoxic controls; $p<0.01$ ) (Fig. $2 A, C$ ). Cortical volume was also $23 \%$ lower in hypoxic-reared mice, or $49.7 \pm 3 \mathrm{~mm}^{3}$ compared with $64.8 \pm 3.7 \mathrm{~mm}^{3}$ in normoxic controls $(p<0.01)$. The overall density of PV-expressing interneurons in the neocortex was $4450 \pm 647$ cells $/ \mathrm{mm}^{3}$ and $8246 \pm 892$ cells $/ \mathrm{mm}^{3}$ in hypoxic and normoxic mice, respectively, a $46 \%$ decrease in hypoxic-reared mice as compared with normoxic controls $(p<0.01)$.

Because it has been well documented that PV cells show ongoing maturation during the first postnatal month (del Río et al., 1994; de Lecea et al., 1995), we examined whether hypoxia-induced deficiencies in $\mathrm{PV}^{+}$cells would change across developmental periods. Thus, we quantified PV-immunoreactive interneurons in the neocortex of normoxic- and hypoxicreared mice perfused at either P35 or in early adulthood, at P47. The number of interneurons that expressed immunohistochemically detectable levels of PV was significantly decreased in the neocortex of hypoxic-reared mice at P35 ( $p<0.01$; Fig. $2 D)$, although the magnitude of this decrease was $32 \%$ and thus smaller $(p<0.01)$ than the 59\% decrease observed at P15. However, contrary to what was seen at P15, there were no significant differences in cortical volume between hypoxic-reared mice and normoxic controls at P35. Analysis at $\mathrm{P} 47$ also revealed a $39 \%$ decrease in $\mathrm{PV}^{+}$ cells in the neocortex of hypoxic-reared mice (Fig. $2 B, E ; p<0.01$ ) and no significant effect of hypoxia on cortical volume. Qualitative assessment indicated that generally, the $\mathrm{PV}^{+}$interneurons in the neocortex of hypoxic-reared mice appeared smaller and less strongly stained when compared with normoxic controls (Fig. 2B). For a quantitative assessment of staining intensity and cell size, see below.

Since we observed such a pronounced deficit in PV expression within the neocortex, we wanted to examine whether other brain areas were affected. An over 2-fold decrease in the number of immunohistochemically detected $\mathrm{PV}^{+}$cells, similar to that observed in the neocortex, was found in the hippocampus at P15 (Fig. $2 F, G ; p<0.01$ ), with the density of hippocampal PVexpressing interneurons also decreasing to $1482 \pm 278$ cells per $\mathrm{mm}^{3}$ in hypoxic mice as compared with $2607 \pm 149$ cells per $\mathrm{mm}^{3}$ in normoxic controls $(p<0.05)$. Hippocampal volume was also decreased in hypoxic-reared mice compared with normoxic controls $\left(9.5 \pm 0.2 \mathrm{~mm}^{3}\right.$ vs $13.7 \pm 1.1 \mathrm{~mm}^{3}$; $p<0.05)$. However, in contrast to the cortex, at P35 and P47
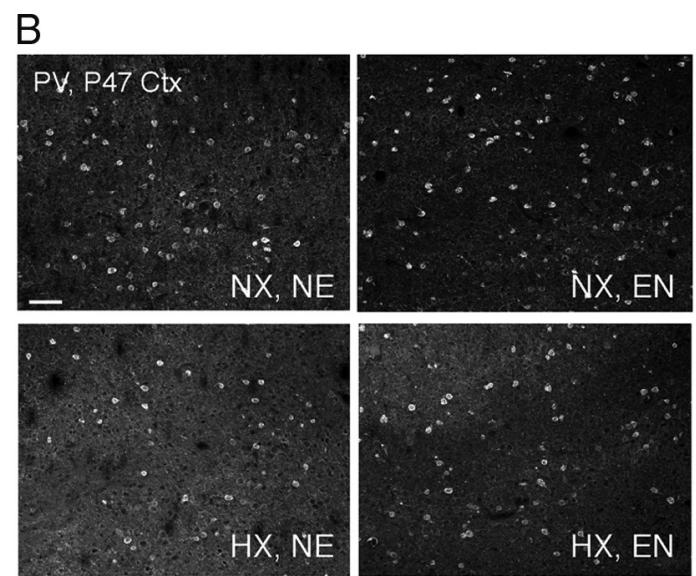

$E$
$\mathrm{D}$

PV Ctx, P35

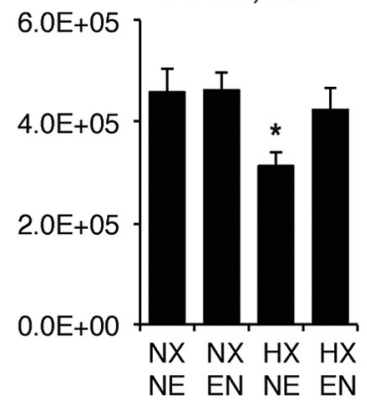

PV Ctx, P47

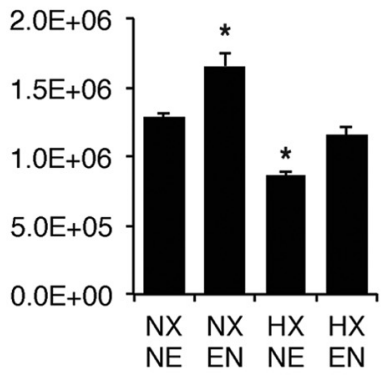

G

$\mathrm{H}$

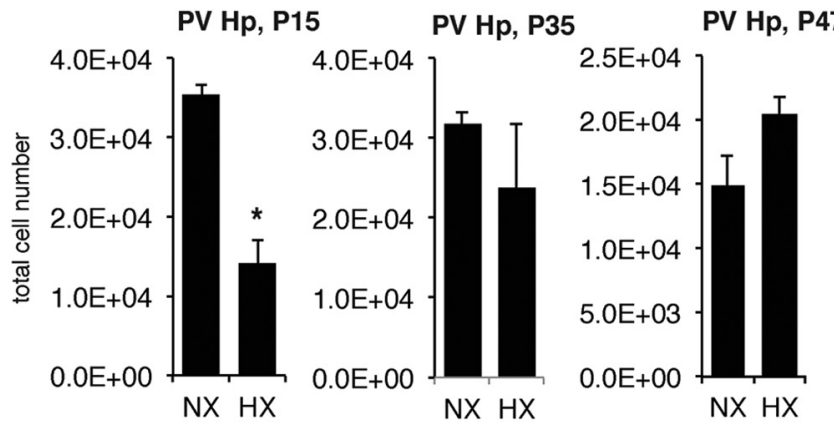

Figure 2. Effects of hypoxic rearing and environmental enrichment on PV-expressing interneurons. $A, B, P V$ immunohistochemistry in the neocortex of normoxic (NX) and hypoxic (HX)-reared mice at P15 (A) and P47 (B); P47 groups of NX and $\mathrm{HX}$ mice were reared in standard, nonenriched (NE) or enriched (EN) environments from P21 until analysis. Stereological quantification of PV ${ }^{+}$cells in P15 (C), P35 (D), and P47 (E) cortex (Ctx) for all four experimental groups. Rearing mice in $\mathrm{HX}$ decreased PV interneuron numbers in neocortex and subsequent EN normalized PV ${ }^{+}$cell numbers (P35: main effect of hypoxia, $p<0.05$; P47: main effect of hypoxia and enrichment, both $p<0.001$ ). $\boldsymbol{F}$-I, Hippocampal (Hp) PV immunolabeling $(\boldsymbol{F})$ and stereological quantification of PV ${ }^{+}$cells at P15 $(\boldsymbol{G}), 35(\boldsymbol{H})$, and $47(\boldsymbol{I})$. Rearing mice in HX decreased PV ${ }^{+}$ interneurons in the hippocampus at P15 but PV ${ }^{+}$cells recovered spontaneously. Scale bars: $20 \mu \mathrm{m}$. Asterisks denote significant differences from all other groups at $p<0.05$.

the numbers of PV-expressing cells in the hippocampus did not differ significantly between normoxic and hypoxic-reared mice; in fact, the number of $\mathrm{PV}^{+}$hippocampal neurons detected immunohistochemically actually showed a trend toward an increase in hypoxic-reared mice at P47 ( $p=0.08$; Fig. $2 H, I)$. Thus, it would seem that the neocortex is uniquely affected with regards to PV expression, and even though there was a degree of spontaneous recovery, the number of PVexpressing interneurons remained significantly decreased in the neocortex of hypoxic-reared mice even at early adulthood, several weeks following the cessation of hypoxia exposure. 


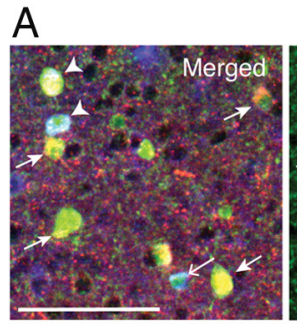

B

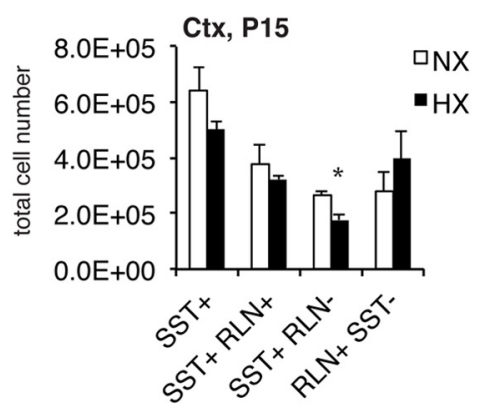

D
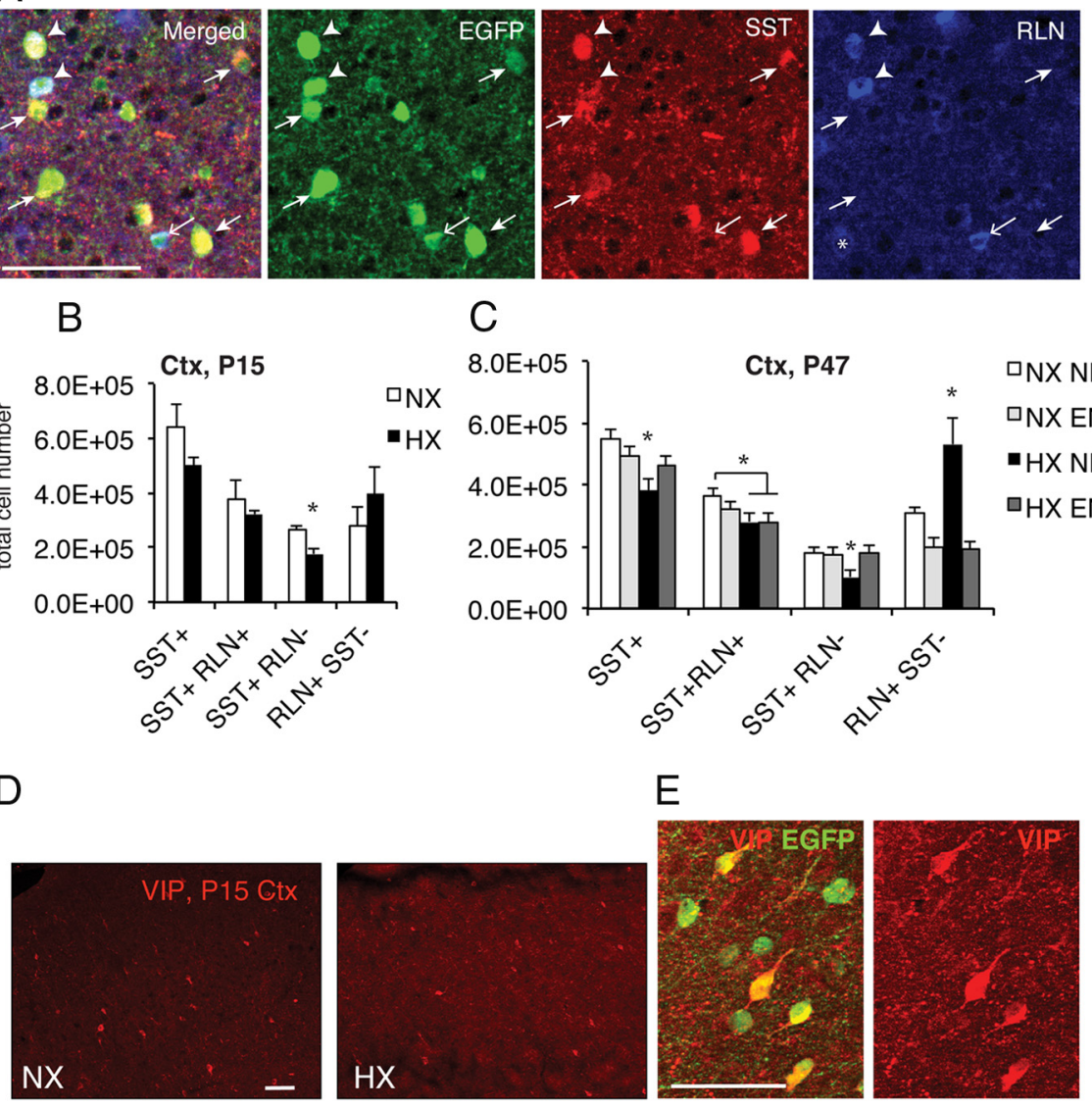

C
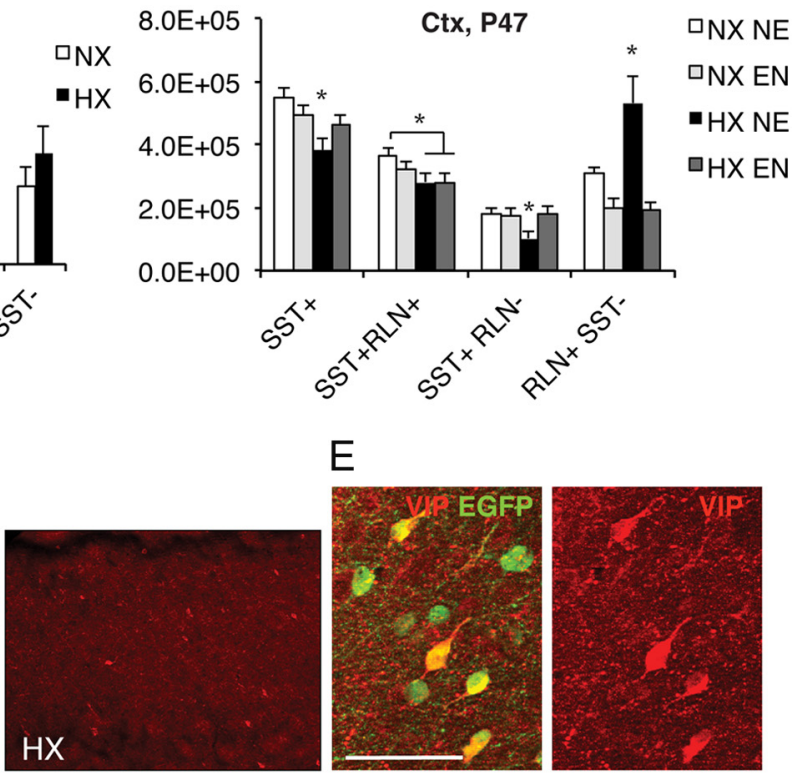

$\mathrm{E}$
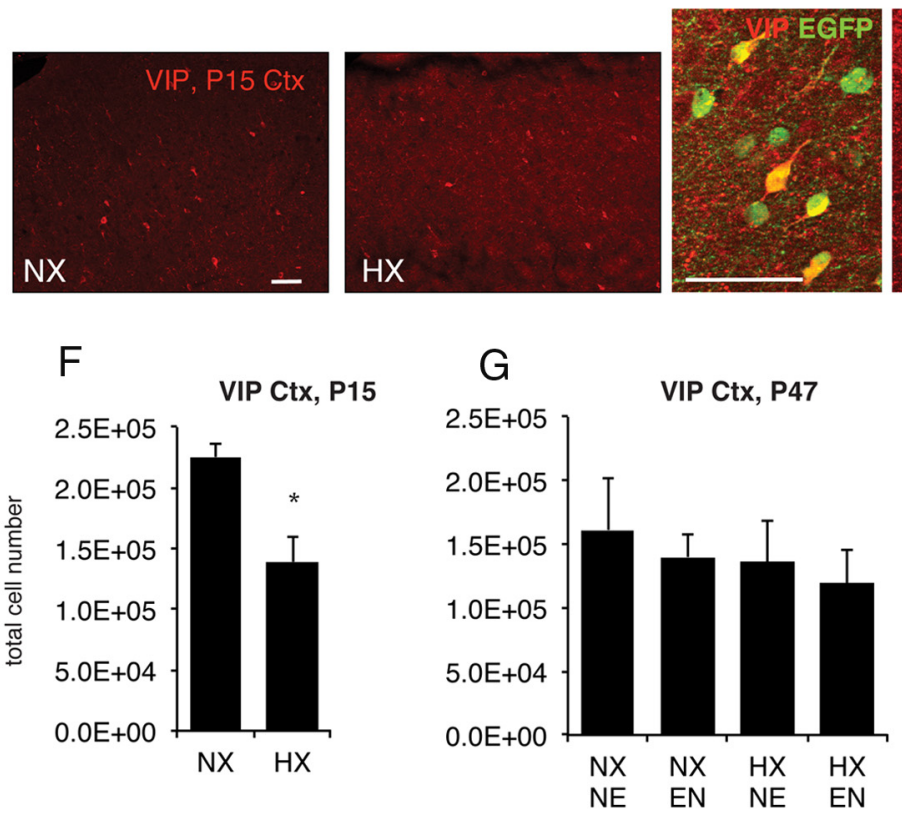

Figure 3. Effects of hypoxic and enriched environment on SST, RLN, and VIP-immunopositive interneurons in neocortex. $A$, Immunolabeling with EGFP, RLN, and SST antibodies in P47 cortex from GAD67-EGFP mice, illustrating the presence of different subpopulations of interneurons: $\mathrm{EGFP}^{+} / \mathrm{SST}^{+} / \mathrm{RLN}^{-}$(small closed arrows), $\mathrm{EGFP}^{+} / \mathrm{SST} /{ }^{+} / \mathrm{RLN}^{+}$(arrowheads), and EGFP ${ }^{+} / \mathrm{RLN}^{+} / \mathrm{SST}^{-}$(open arrow). Asterisk indicates an EGFP ${ }^{-} /$RLN $^{+} /$SST ${ }^{-}$cell. $B, C$, Stereological quantification of EGFP ${ }^{+}$cells coexpressing SST and/or RLN at P15 (B) and at P47 (C). BothSST ${ }^{+} / \mathrm{RLN}^{-}$andSST ${ }^{+} / \mathrm{RLN}^{+}$interneurons were decreased in hypoxic-reared mice, but while the first recovered to control levels with subsequent enrichment, $S S T^{+} / \mathrm{RLN}^{+}$interneurons did not recover with subsequent enrichment. In contrast, $\mathrm{RLN}^{+} /$ $\mathrm{SST}^{-}{ }^{-}$interneurons increased after hypoxia and were also normalized with enriched environment at P47. D, Decreased number VIP ${ }^{+}$ interneurons in P15 hypoxic cortex (Ctx) shown by immunostaining with VIP antibodies; stereological quantification shown in F. E, Higher magnification image of supragranular Ctx demonstrating that all VIP ${ }^{+}$cells coexpress GAD67-EGFP at P15. G, Stereological quantification of VIP ${ }^{+}$cells in neocortex at P47 showing that VIP ${ }^{+}$cells recovered spontaneously and there was no further effect of enriched environment. NX NE, normoxic nonenriched; NXEN, normoxic enriched; HX NE, hypoxic nonenriched; HXEN, hypoxic enriched. Scale bars: $20 \mu \mathrm{m}$. Asterisks denote significant differences from all other groups at $p<0.05$.

The hypoxia-induced deficits in PV interneuron immunoreactivity coincide with a developmental period during which this neuronal population undergoes key maturation based in part on excitatory neuronal input (Patz et al., 2004; Sugiyama et al., 2008). To test the hypothesis of whether the negative effects of hypoxia on neocortical interneurons could be mitigated by an

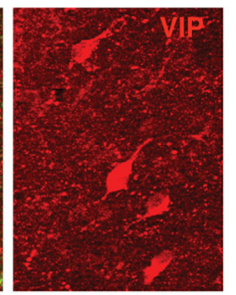

activity-rich environment, we exposed mice that had been previously reared in normoxic or hypoxic conditions to an enriched environment from weaning at $\mathrm{P} 21$ until perfusion. The number of PVexpressing interneurons in the neocortex of these animals was then compared with the numbers in mice that had been housed in standard laboratory cage conditions. Environmental enrichment was constructed by housing mice in spacious group cages equipped with a running wheel as well as various toys, thus providing mice with opportunities for voluntary physical activity as well as novelty exploration and learning situations (Fig. 1B; Salmaso et al., 2012). We found that at both P35 and P47, environmental enrichment following hypoxia significantly increased the number of $\mathrm{PV}$-immunoreactive interneurons in neocortex (Fig. 2 B, D,E; P35:main effect of hypoxia, $p<0.05$; P47: main effect of hypoxia, $p<0.001)$. In contrast to standard housed mice, hypoxic-reared mice that were exposed to enriched environment no longer exhibited a significant deficit in PVimmunoreactive interneurons, such that they were no different from normoxic controls. Interestingly, environmental enrichment also increased PV expression in the cortex of normoxic mice, but only at P47 (Fig. 2E; P47: main effect of enrichment, $p<$ $0.001)$.

Hypoxia induces a persistent decrease in neocortical SST expression and a delayed increase in RLN expression, which are normalized by environmental enrichment

To ascertain whether the effects of hypoxia and enrichment were restricted only to $\mathrm{PV}^{+}$interneurons, we quantified the numbers of cells expressing immunocytochemical markers for other subtypes of cortical interneurons. In addition to $\mathrm{PV}$, other major subclasses of GABA interneurons are the SST-immunopositive cells $\left(\mathrm{SST}^{+}\right)$, which are subdivided into SST interneurons that coexpress RLN $\left(\mathrm{SST}^{+} / \mathrm{RLN}^{+}\right)$or lack detectable RLN expression $\left(\mathrm{SST}^{+} / \mathrm{RLN}^{-}\right)$and the RLNimmunopositive but SST-immunonegative cells $\left(\mathrm{RLN}^{+} / \mathrm{SST}^{-}\right)$(Fig. $\left.3 A\right)$. Finally, there are VIP-expressing $\left(\mathrm{VIP}^{+}\right)$interneurons (Fig. 3E) (Fig. 1D; for a schematic outline of cortical interneurons subtypes; Wonders and Anderson, 2006; Gelman and Marín, 2010; Rudy et al., 2011).

Only two of the aforementioned interneuron subclasses showed alterations of immunohistochemically detectable marker expression within the neocortex of hypoxic-reared mice at P15: $\mathrm{SST}^{+} / \mathrm{RLN}^{-}$interneurons (32\% decrease, $p<0.05$; Fig. $3 B$ ) and $\mathrm{VIP}^{+}$interneurons $(38 \%$ decrease, $p<0.05$; Fig. $3 D, F)$. VIP 

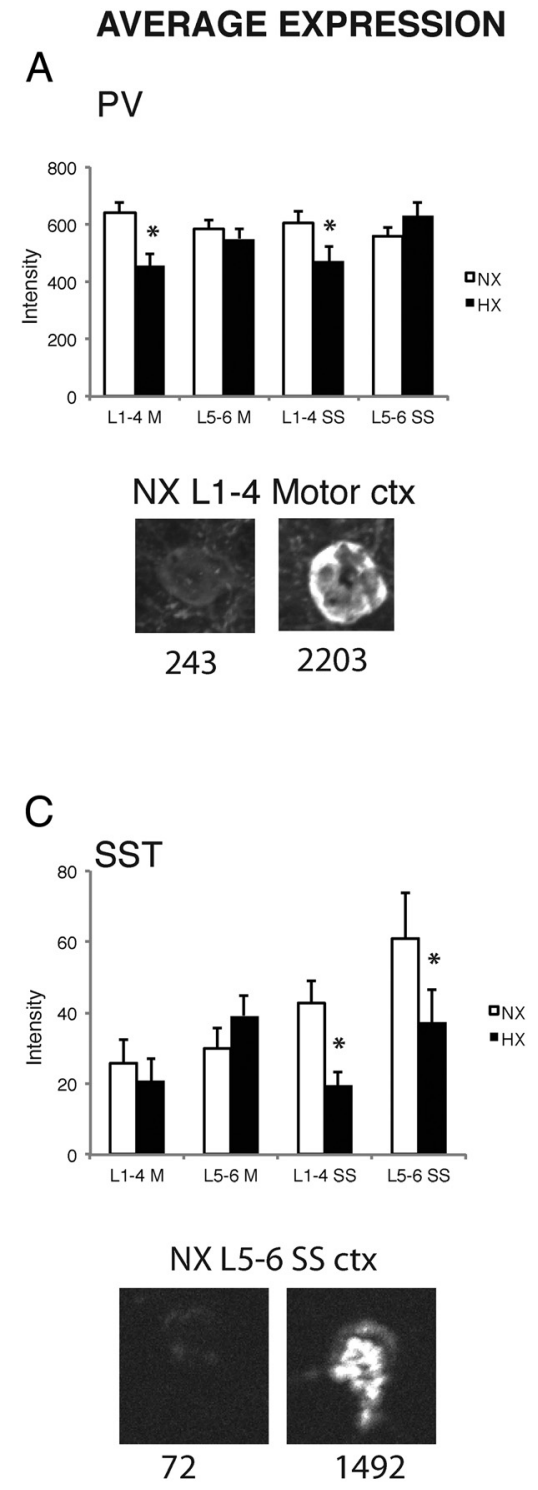

E

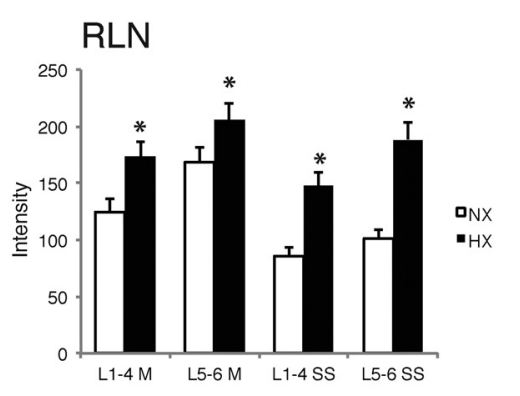

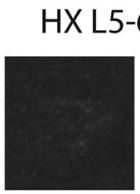

86

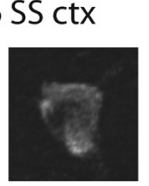

634
$\mathrm{B}$

\section{NUMBER OF CELLS WITH DISTINCT EXPRESSION LEVELS}

PV-Motor CTX
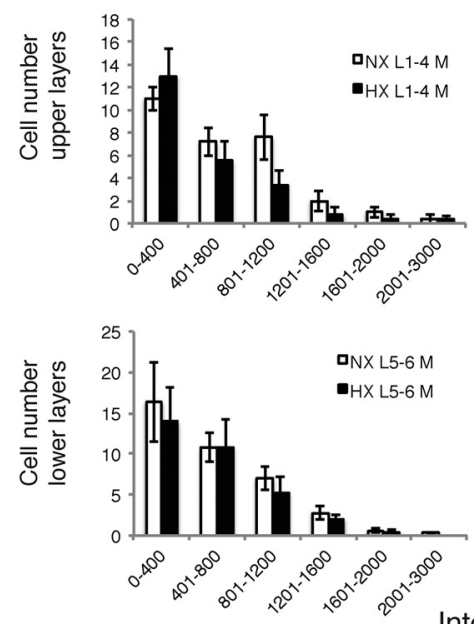

Intensity categories

PV-Somatosensory CTX
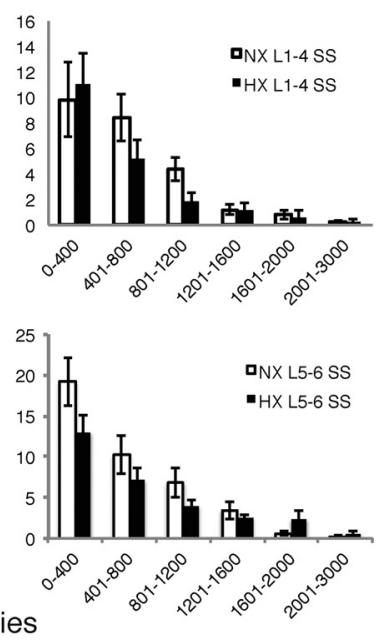

$\mathrm{D}$

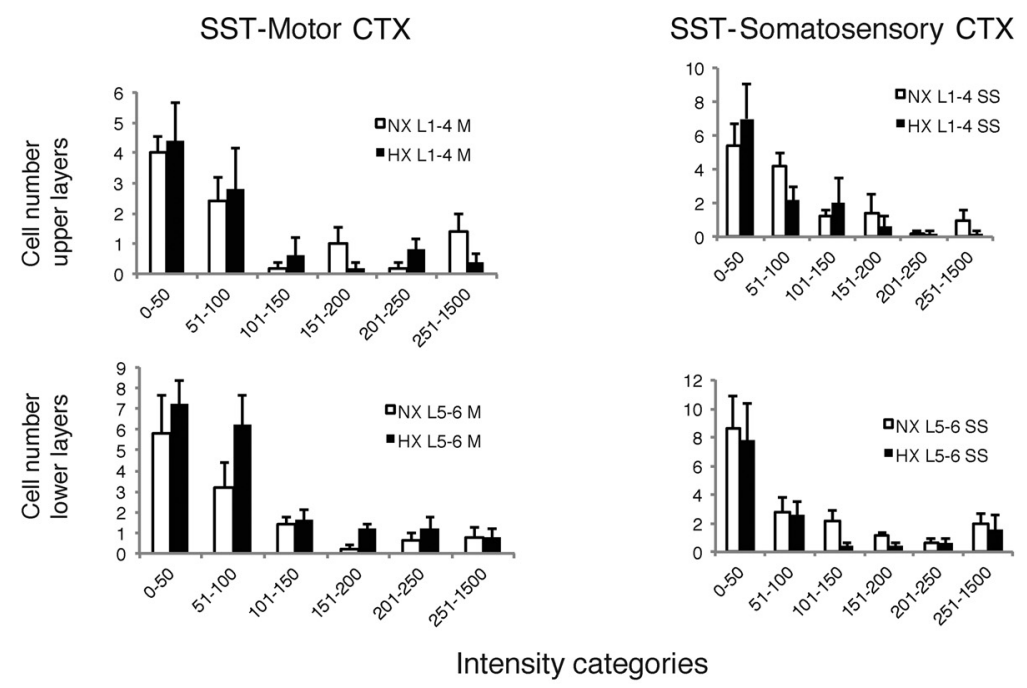

F

RLN-Motor CTX

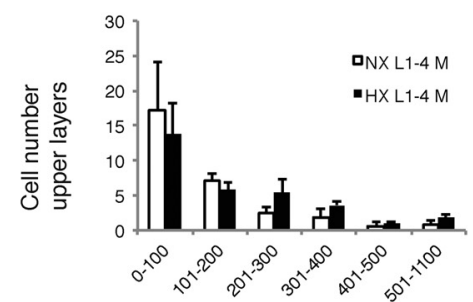

RLN-Somatosensory CTX
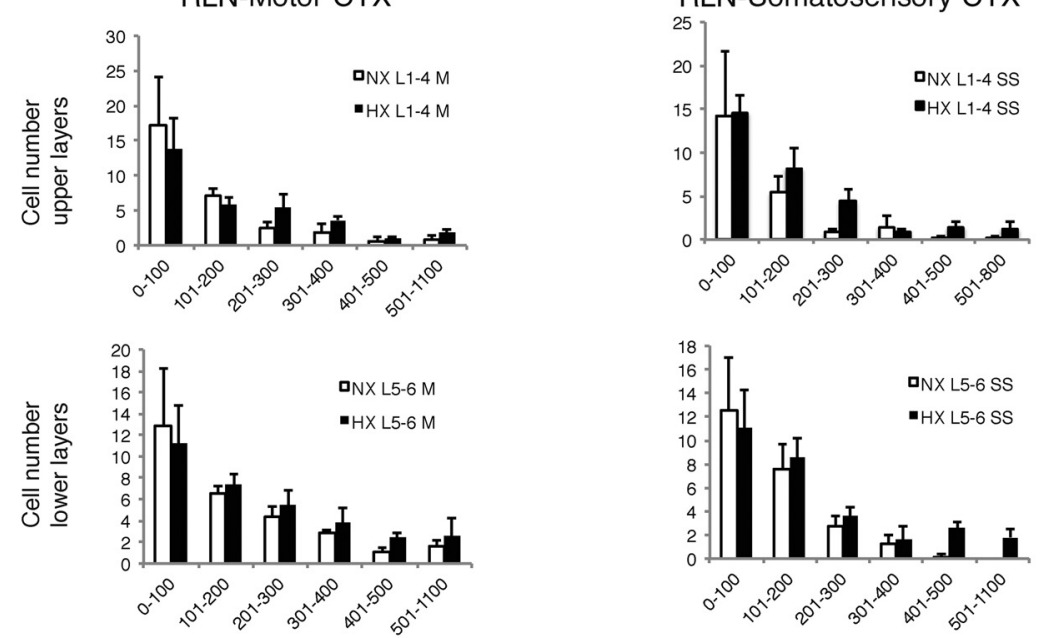

Intensity categories

Figure 4. Intensity and distribution of expression of interneuron marker expression in upper (L1-L4) and lower (L5-L6) layers of primary motor or primary somatosensory cortex (hindlimb) of normoxic and hypoxic mice at P47. Quantification of average expression and numbers of cells with distinct expression levels, respectively, with regards to PV $(\boldsymbol{A}, \boldsymbol{B})$, (Figure legend continues.) 
expression recovered spontaneously at P47 and was unaffected by enrichment status (Fig. 3G). In contrast, at P47, both overall SST-expressing cells as well as those that colocalized RLN or showed no RLN immunolabeling were significantly decreased by hypoxia ( $p<0.05$; Fig. $3 C$ ). Introduction of environmental enrichment upon weaning at P21, i.e., $10 \mathrm{~d}$ after the end of chronic hypoxia, was sufficient to correct the above-mentioned hypoxiainduced decrease in SST ${ }^{+}$and SST ${ }^{+} / \mathrm{RLN}^{-}$cells (Fig. $3 C$; $\mathrm{SST}^{+}$: main effect of hypoxia $p<0.05$; $\mathrm{SST}^{+} / \mathrm{RLN}^{-}$interaction between normoxia/hypoxia and standard/enrichment: $p=0.054)$. In contrast, the number of SST-immunoreactive cells that coexpress RLN was not modified by enrichment status (Fig. 3C). Intriguingly, the $\mathrm{RLN}^{+} / \mathrm{SST}{ }^{-}$interneuron subpopulation showed a remarkable $73 \%$ increase at $\mathrm{P} 47$ in hypoxic-reared mice (Fig. $3 C$ ), which was totally reversed by enrichment (Fig. $3 C$; interaction between normoxia/hypoxia and standard/enrichment $p<$ 0.05). Notably, these counts were performed in GAD67-EGFP mice, hence we only counted the EGFP ${ }^{+} / \mathrm{RLN}^{+}$GABAergic cells, which is important as RLN has been shown to also be present in some projection neurons in the cortex (Deguchi et al., 2003).

\section{Quantification of intensity and distribution of expression of interneuron marker expression in cortex of $\mathrm{P} 47$ normoxic and hypoxic mice}

During our stereological cell counts it was evident that markerpositive cells exhibited varying levels of immunolabeling. To gain a more detailed understanding of the effects of hypoxia on interneuron marker expression, we quantified the intensity levels of labeling with PV, SST, and RLN antibodies in individual interneurons (GAD67-EGFP ${ }^{+}$cells) as well as counted markerpositive cells using micrographs of RLN/SST and PV/RLN double-immunostained sections from P47 GAD67-EGFP brains. We evaluated potential regional effects within the cortex by mapping the distribution of marker-positive cells of varying labeling intensities in two areas along the rostrocaudal axis, primary motor (M1) and primary somatosensory cortex, hindlimb region $(\mathrm{S} 1 \mathrm{HL})$, and in the upper (L1-L4) and lower (L5, L6) cortical layers.

The intensity of PV immunostaining was significantly decreased by 28 and $21 \%$, respectively, in upper cortical layers of motor and somatosensory cortex in hypoxic mice (interaction between hypoxia and cortical layer distribution, $p<0.01$; Fig. $4 A$ ). However, hypoxia did not significantly affect the amount of PV expression in deep cortical layers of either cortical region. When we evaluated the distribution of $\mathrm{PV}^{+}$cell numbers among six different intensity categories of PV expression, hypoxia decreased the numbers of $\mathrm{PV}^{+}$cells across all intensity ranges in both motor and somatosensory cortex (Fig. 4B; interaction between number and intensity ranges not significant). When considering all intensities together, numbers of PV-expressing cells were significantly decreased by $20 \%$ in hypoxic mice without any interactions by cortical region or layer localization (main effect of hypoxia $p<0.05$ ). We also found that $\mathrm{PV}^{+}$cells exhibited a significantly decreased cell size but only in upper cortical layers of motor cortex $(15.1 \pm 0.4$ and $13.5 \pm 0.5 \mu \mathrm{m}$ in normoxic and

$\leftarrow$

(Figure legend continued.) $\quad \mathrm{SST}(\boldsymbol{C}, \boldsymbol{D})$, and RLN $(\boldsymbol{E}, \boldsymbol{F})$. Asterisks denote significant differences $(p<0.05)$ as determined by factorial ANOVA conducted for each marker. Images depict representative examples of single cells expressing low or high levels of a given marker. The numbers signify the background corrected intensity of cell fluorescence for each cell and marker. NX, normoxia; HX, hypoxia; M, motor cortex; SS, somatosensory cortex; L1-4, cortical layers 1-4; L5-6, cortical layers 5 and 6 ; ctx, cortex. hypoxic mice, respectively; interaction between hypoxia and upper/lower cortical layer distribution, $p<0.001$ ).

Next, we quantified levels of SST immunoreactivity in individual cells in upper and lower layers of motor and somatosensory cortex. Expression of SST was significantly decreased by hypoxia in upper as well as in lower cortical layers of somatosensory cortex (54 and 39\% decrease, respectively) but was not significantly affected in motor cortex (interaction between hypoxia and cortical layer distribution, $p<0.05$; Fig. $4 C$ ). When we evaluated the distribution of $\mathrm{SST}^{+}$cell numbers among six different intensity categories of SST expression, hypoxia seemed to decrease $\mathrm{SST}^{+}$cells in the medium intensity ranges, but had a variable effect in the low intensity range, such that when considering all intensities together, the total number of SST-immunoreactive cells was not significantly changed by hypoxia (Fig. 4D). However, the subset of SST ${ }^{+} / \mathrm{RLN}^{-}$cells was decreased by hypoxia in somatosensory cortex by 81 and 53\% in upper and lower cortical layers, respectively (interaction between hypoxia and motor/somatosensory cortex distribution, $p<0.01$; interaction between hypoxia and upper/lower cortical layer distribution, $p<0.05$; data not shown). The size of SST + cells was not affected by hypoxia (data not shown).

Finally, we quantified the levels of RLN immunostaining in individual cells in upper and lower layers of motor and somatosensory cortex. We found that hypoxia increased the intensity of RLN immunostaining in all regions and layers examined (Fig. $4 E)$, with a trend toward a stronger effect in somatosensory cortex (main effect of hypoxia $p<0.0001$; interaction between hypoxia and motor/somatosensory cortex distribution, $p=0.068$; Fig. $4 E)$. Furthermore, hypoxia increased the numbers of $\mathrm{RLN}^{+}$cells in the medium to high intensity ranges, but did not affect the numbers of $\mathrm{RLN}^{+}$cells in the low intensity categories, which were the most numerous. When considering all intensities together, the numbers of $\mathrm{RLN}^{+}$cells were unchanged by hypoxia in both regions (Fig. $4 F$ ). Hypoxia exhibited a complex effect on $\mathrm{RLN}^{+}$cell size. Hypoxia decreased $\mathrm{RLN}^{+}$cell size in upper layers of motor cortex $(12.1 \pm 0.3 \mu \mathrm{m}$ vs $10.8 \pm 0.3 \mu \mathrm{m}$ in normoxic and hypoxic mice, respectively) and increased $\mathrm{RLN}^{+}$cell size in lower layers of somatosensory cortex (11.6 \pm $0.3 \mu \mathrm{m}$ vs $12.9 \pm 0.3 \mu \mathrm{m}$ in normoxic and hypoxic mice, respectively; interaction between hypoxia and cortical region distribution, $p<0.001$; interaction between hypoxia and cortical layer distribution, $p<0.05$ ).

Last, we evaluated any potential relationship between RLN and SST expression or RLN and PV expression in sections double stained for RLN and SST or PV and RLN. There was no significant correlation (negative or otherwise) between RLN and SST intensity across double-labeled cells. When we evaluated colabeling between PV and RLN, we found that very few $\mathrm{PV}^{+}$cells coexpressed RLN. Interestingly, they were increased in hypoxic cortex, specifically in upper layers. However, since they were so few (on average $0.2-2.1$ cells per section) we could not perform a meaningful correlation analysis of PV and RLN expression.

In conclusion, combining measurements of immunostaining intensities of marker-positive individual cells with cell counts in motor and somatosensory cortex suggests that hypoxia decreases the number of $\mathrm{PV}^{+}$cells across all intensity ranges and in all regions and layers examined, decreases the number of $\mathrm{SST}^{+}$cells in the medium intensity range in the somatosensory cortex, and increases RLN immunoreactivity in the medium to high intensity ranges with no overall change in $\mathrm{RLN}^{+}$cell number. 
Hypoxia does not alter the total number of interneurons in cerebral cortex

Next, we examined whether the hypoxiainduced decreases in immunostaining for interneuron markers were due to an actual loss of interneurons. To this end, we estimated the total numbers of GAD67-EGFP ${ }^{+}$ GABA interneurons in the same cohorts of mice in which we had observed decreased staining of interneuron marker ${ }^{+}$cells. We used the GAD67-EGFP line wherein virtually all inhibitory GABA interneurons are fully labeled with EGFP reporter from embryogenesis onward (Tamamaki et al., 2003). The EGFP reporter protein in these mice does not change with maturation or plasticity of GABA interneurons throughout early postnatal development (Fig. $5 B, C$ ) likely due to stability of the EGFP protein, allowing an estimation of their number independently from their maturation stage (Jiao et al., 2006). In this new cohort of animals, we still observed persistent decreases in numbers of immunohistochemically detected $\mathrm{PV}^{+}$cells with a subsequent recovery after environmental enrichment, as well as an increase in $\mathrm{PV}^{+}$cells in normoxicenriched mice (Fig. 5C). However, the numbers of EGFP reporter-positive interneurons in neocortex did not differ significantly between normoxic and hypoxic mice, neither at $\mathrm{P} 15$ nor at $\mathrm{P} 47$ (Fig. 5A-C). The total numbers of GAD67-EGFP reporter-positive cells per cortex were $2,626,693 \pm 136,824$ in normoxic mice versus 2,259,182 $\pm 136,303$ in hypoxic-reared mice at P15. At P47, the total numbers of reporter-positive interneurons were $2,448,017 \pm 185,196$ and 2,598,123 \pm 171,593 in normoxic and hypoxic mice, respectively. Furthermore, we found no significant differences in total $\left(\mathrm{EGFP}^{+}\right)$ inhibitory interneuron numbers between mice housed in standard laboratory environment and environmentally enriched mice at P47 (Fig. 5C).

To directly examine whether cell death was responsible for the pronounced loss of PV interneuron marker-positive cells at P15, we colabeled cells with EGFP and the apoptotic marker activated caspase- 3 in brain sections from GAD67-EGFP mice. Very few apoptotic cells were identified per neocortex with no significant differences in the numbers of activated caspase $-3^{+}$cells between normoxic controls and hypoxic-reared mice. Moreover, there was no overlap between activated caspase- 3 and EGFP (Fig. 5D). To understand whether GABA interneuron progenitor cells were dying, we analyzed brain sections from mice perfused imme-
A
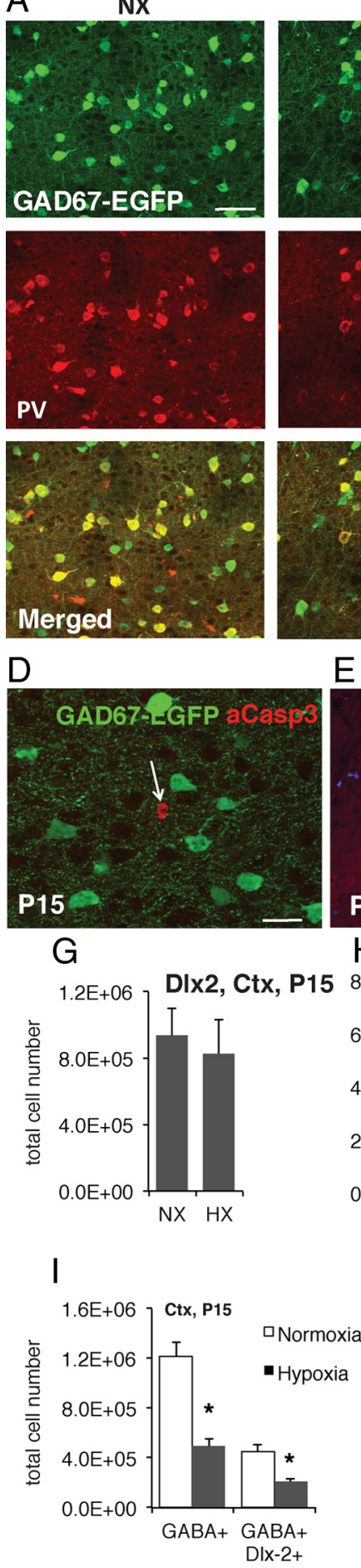

E
B

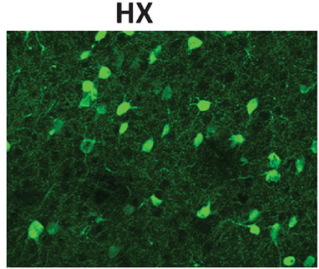

GAD67-EGFP, Ctx, P15

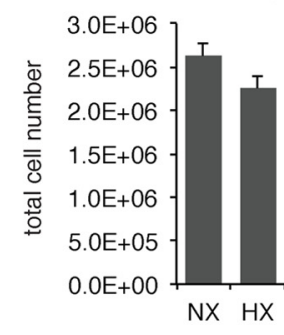

C GAD67-EGFP, Ctx,P47

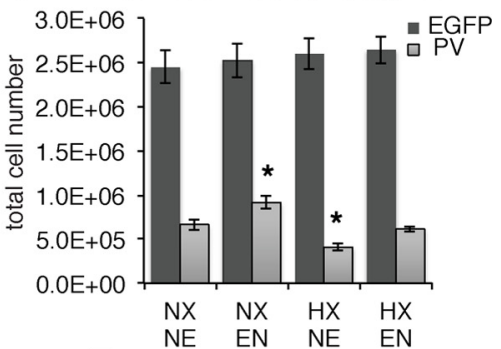

F
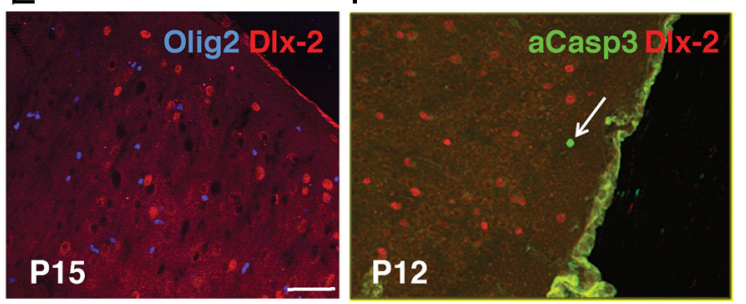

$\mathrm{H}$

8.0E+05 DIx2, Ctx, P47
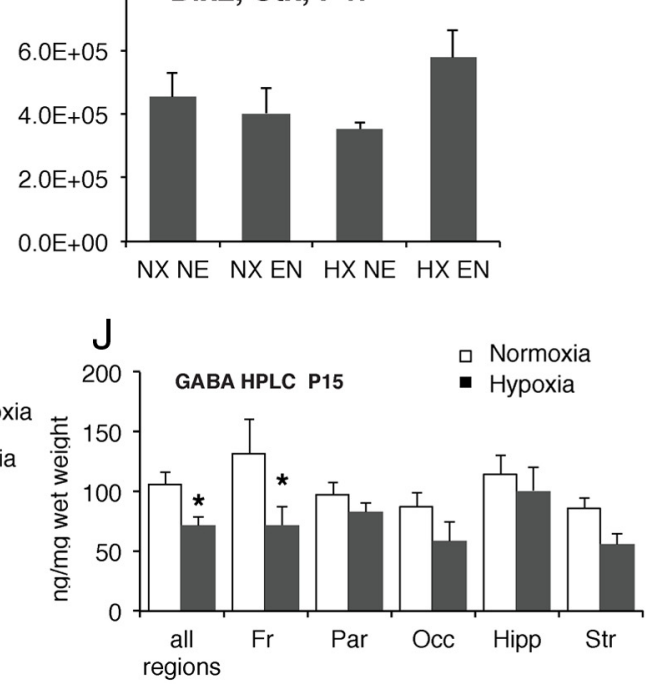

Figure 5. Analysis of interneuron lineage cells in the neocortex. $A$, Costaining of PV (red) and GAD67-EGFP reporter (green) in P15 cortex (Ctx). B, C, Stereological quantification of GAD67 EGFP ${ }^{+}$cells in the cortex (Ctx) at P15 (B) and P47 (C). EGFP ${ }^{+}$cell numbers do not change across conditions, whereas $\mathrm{PV}^{+}$cells counted in the same sections are decreased by hypoxia $(\mathrm{HX})$ and increased by enriched environment (EN). D-F, P12-P15 neocortex from HX-reared mice labeled with antibodies to activated caspase-3 (red) and GAD67-EGFP (green; $\boldsymbol{D}$ ), Dlx-2 (red), and Olig2 (blue; $\boldsymbol{E}$ ), and activated caspase-3 (green) and Dlx-2 (red; $\boldsymbol{F}$ ). Interneurons do not undergo noticeable increases in cell death in response to rearing in HX. $\mathbf{G}, \boldsymbol{H}$, Stereological quantification of Dlx-2 ${ }^{+}$cells in P15 $(\boldsymbol{G})$ and P47 $(\boldsymbol{H})$ neocortex. There are no significant changes in Dlx-2 ${ }^{+}$cell numbers in response to HX or EN. $\boldsymbol{I}$, The numbers of all GABA ${ }^{+}$cells and GABA ${ }^{+}$Dlx- $2^{+}$colabeled cells in P15 cortex were decreased in HX-reared mice. J, HPLC measurement of GABA content in different brain regions showed that $\mathrm{HX}$ rearing significantly decreased GABA in frontal cortex. Scale bars: $\boldsymbol{A}, \boldsymbol{E}, 20 \mu \mathrm{m} ; \boldsymbol{D}, 10 \mu \mathrm{m}$. Asterisks denote significant differences from normoxic controls at $p<0.05$. NX NE, normoxic nonenriched; NX EN, normoxic enriched; HX NE, hypoxic nonenriched; HX EN, hypoxic enriched; Fr, frontal; Par, parietal; Occ, occipital, Hipp, hippocampus; Str, striatum. 
diately after hypoxic rearing (P12) that were colabeled with activated caspase- 3 and the transcription factor Dlx-2, which is expressed in GABAergic progenitors since embryogenesis (Bulfone et al., 1993). The Dlx-2 protein showed complete overlap with inhibitory neuron lineage markers such as GAD67-EGFP and was also occasionally coexpressed with mature interneuron markers such as PV; Dlx-2 was not expressed in oligodendrocyte lineage cells, labeled by the transcription factor Olig2 (Fig. 5E). Again, there was no difference in numbers of caspase- $3^{+}$cells between normoxia and hypoxia-reared mice and almost all of the activated caspase $-3^{+}$cells identified in neocortex lacked Dlx-2 expression (Fig. 5F). Consistent with the idea that there was no death of interneuron progenitors or immature GABA neurons in hypoxic-reared mice, neither hypoxia nor environmental enrichment had any significant effects on the numbers of Dlx-2-positive cells in P15 or P47 brains (Fig. 5G,H). Together, our data showing unchanged numbers of total interneurons and interneuron progenitors and lack of cell death strongly suggest that the pronounced and significant decreases in PV and SST cortical interneuron immunoreactivity (Figs. 2, 3) were not due to a de facto loss of interneurons.

\section{Hypoxia decreases GABA content in the neocortex}

The fact that the numbers of immunohistochemically detected $\mathrm{PV}^{+}$and $\mathrm{SST}^{+} / \mathrm{RLN}^{-}$interneurons, which together comprise the majority of cortical inhibitory cells, were significantly decreased by hypoxia and increased by enrichment, but the total number of inhibitory neurons (marked by EGFP) and their progenitors did not differ between these conditions, suggests that hypoxia and enrichment might somehow influence the expression of mature interneuron markers. It is well established that $\mathrm{PV}^{+}$neurons undergo their final differentiation in the first three postnatal weeks and therefore their phenotypic maturation could be susceptible to environmental manipulations during this time. Unlike the EGFP reporter driven by the gad 1 promoter, the expression of GAD67 mRNA and protein undergo a steady upregulation with increased maturation of interneurons during the early postnatal period (Huang and Akbarian, 2007) and are affected by sensory deprivation (Jiao et al., 2006). We thus considered levels of GABA neurotransmitter expression in the brain as a marker of interneuron maturity and function.

To test this hypothesis, we first evaluated colocalization between the inhibitory neurotransmitter GABA and GAD67 in double-immunolabeled sections from normoxic adolescent mice and found that there was a large overlap between the two markers $\left(85 \%\right.$ of strongly $\mathrm{GAD} 7^{+}$cells were also $\left.\mathrm{GABA}^{+}\right)$, thus allowing us to use these phenotypes interchangeably. We chose to use GABA as a marker since the positive staining was mainly perisomatic and positive cells could be unequivocally identified in contrast to GAD67, where positive cells not only exhibited staining of the cell body but also strong punctuate staining of processes, which made cell counts more difficult. To obtain a molecular index of maturation of the Dlx-2-positive interneuron lineage cells in neocortex, we costained sections from P15 mice with antibodies for Dlx-2 and GABA. We found that the total numbers of $\mathrm{GABA}^{+}$cells $(p<0.001)$ as well as $\mathrm{GABA}^{+} / \mathrm{Dlx}-2^{+}$ $(p<0.001)$ cells were significantly and comparably decreased in the cortex of hypoxia-reared mice as compared with normoxic controls at P15 (Fig. 5I). To confirm the changes we observed in GABA immunolabeling, we measured GABA content in different parts of the cortex and in other brain areas such as basal ganglia and hippocampus using HPLC. Hypoxic-reared mice exhibited lower GABA content in general, with the most pronounced difference in frontal cortex, confirming our cell counts (Fig. 5J; $p<0.05$ ).

The decrease in the fraction of Dlx ${ }^{+}$cells expressing detectable GABA levels at P15 by immunohistochemistry, together with absence of changes in total numbers of GAD67-EGFP ${ }^{+}$cells or Dlx-2 ${ }^{+}$interneuron progenitors, suggest that hypoxia is likely to delay interneuron maturation in the cortex. The data also suggest that there is some degree of catch-up in hypoxic mice, as $\mathrm{PV}^{+}$interneurons are relatively less depleted at P47, 5 weeks after hypoxia, as compared with P15. Hence, we were interested to assess whether GABA immunoreactivity also exhibited an improvement at several weeks after hypoxia. In the cortex of hypoxic-reared mice at P47, the numbers of GABAimmunoreactive cells were not significantly different from normoxic mice $\left(1,018,842 \pm 180,272\right.$ and $936,433 \pm 25,288 \mathrm{GABA}^{+}$ cells in hypoxic and normoxic mice, respectively).

\section{Recovery of interneuron subpopulations after hypoxia and environmental enrichment is not due to neurogenesis}

Since it has previously been shown that GABAergic GAD67 ${ }^{+}$ interneuron progenitors in cortical layer 1 can be induced to proliferate and replenish interneuron populations after a hypoxic-ischemic insult (Ohira et al., 2010), we examined P15 cortical sections for colabeling of GABA with the proliferation marker Ki67. However, we found no evidence of $\mathrm{Ki} 67^{+}$cells that coexpressed GABA in either normoxic or hypoxic-reared mice (Fig. 6A,B). Moreover, we immunolabeled sections from P15 mice with Ki67 and Dlx-2 as an additional assessment of whether inhibitory interneuron progenitors were induced to proliferate in response to hypoxia. Dlx- $2^{+}$cells were almost exclusively Ki67 negative (Fig. $6 \mathrm{C}$ ) and thus, likely to be postmitotic in both normoxic and hypoxic mice. Last, we did not find any overlap between GAD67-EGFP and Ki67 at P15 (Fig. 6D). We therefore concluded that there was no evidence of proliferation of GABA interneuron lineage cells in P15 cortex in any of the conditions. This suggests that the partial recovery of interneuron populations observed at later time points after hypoxia are likely not due to neurogenesis from interneuron progenitor cells.

To further assess whether enriched environment led to generation of inhibitory interneurons in the neocortex, we administered the thymidine analog BrdU to GAD67-EGFP hypoxic-reared mice and normoxic controls between P21-P27, immediately upon weaning and onset of enriched or standard cage conditions, and perfused the mice 4 weeks later. The numbers of $\mathrm{BrdU}^{+}$cells were significantly increased in the cortex of hypoxic-reared nonenriched mice versus normoxic controls $(251,931 \pm 24,684 \mathrm{BrdU}+$ cells vs $128,565 \pm 12,846 \mathrm{BrdU}^{+}$cells; $\left.p<0.05\right)$. However, environmental enrichment had no effect on the number of BrdU-labeled cells. $\mathrm{BrdU}^{+}$GAD67-EGFP colabeled cells were rarely found and if so, they were only present in normoxic but not in hypoxic mice, regardless of enriched housing status. Most of the $\mathrm{BrdU}^{+}$cells did not coexpress GAD67-EGFP (Fig. 6E,F); not surprisingly, as we have previously reported that newborn cells labeled after hypoxia mostly express oligodendrocyte and astroglial markers (Fagel et al., 2006).

We next examined whether GABAergic neurons could be generated in enriched animals from a non-GABAergic lineage. Using genetic fate mapping, we recently demonstrated that hypoxia increases the genesis of cortical excitatory neurons from $\mathrm{GFAP}^{+}$ cells in juvenile mice (Bi et al., 2011). To examine whether $\mathrm{GFAP}^{+}$cells were able to generate new GABAergic neurons in response to environmental enrichment, tamoxifen-inducible GCE mice carrying the CAG-CAT-EGFP or the R26R LacZ reporter were reared in hypoxic or normoxic conditions, injected 
with tamoxifen daily from P12 to P14 and then subjected to enrichment starting from P21 until P35 or P47. When we analyzed coexpression between reporter and inhibitory interneuron markers in the neocortex at P35, there were no reporter ${ }^{+}$ cells that coexpressed GABA in normoxic or hypoxic nonenriched mice. However, in 1 of 3 normoxic-reared enriched mice and in 2 of 4 hypoxic-reared enriched mice, reporter ${ }^{+}$cells that coexpressed GABA were observed. These doublelabeled putative inhibitory interneurons were, however, very rare. They constituted $1 \%$ among reporter ${ }^{+}$cells or $0.3 \%$ among $\mathrm{GABA}^{+}$cells in the normoxic enriched mouse, and 2\% among reporter ${ }^{+}$ cells or $0.9 \%$ among $\mathrm{GABA}^{+}$cells in the two hypoxic-reared enriched mice. These rare reporter ${ }^{+}$cells that coexpressed GABA were NeuN negative and exhibited an immature morphology with a small cell body and very few processes. We then analyzed reporter-tagged GFAP-lineage cells in the neocortex at P47. As previously described (Bi et al., 2011), we observed multiple reporter-positive cells with neuronal morphology in the cortex of mice from all four groups. These reporter ${ }^{+}$cells, however, exhibited pyramidal cell morphology and none of them coexpressed PV (Fig. $6 G-L$ ) or $\mathrm{CR}$, an interneuron marker expressed in a subpopulation of SST and VIP-positive cells (data not shown). In contrast, many reporter ${ }^{+}$cells expressed the excitatory neuron transcription factor Tbr1 and exhibited complex dendritic architecture in enriched environment mice (Fig. 6M-O). Together, our data suggest that the recovery of interneurons after hypoxia and environmental enrichment is, for the most part, not due to generation of new neurons.

\section{Discussion}

This study presents compelling evidence that our model of hypoxic brain injury, which is clinically relevant to prematurely born infants, results in a long-lasting decrease perturbation in the differentiation of $\mathrm{PV}^{+}$and $\mathrm{SST}^{+}$interneuron subtypes within the neocortex, coupled with a transient decrease in overall GABA neurotransmitter content, most notably in the frontal cortex. Introducing hypoxic-reared mice into an enriched environment for $\sim 1$ month largely normalized the neurochemical profile of inhibitory interneurons.

Our analysis showed that rather than affecting the total number of interneurons, hypoxia decreased the expression of RLN and SST and increased the expression of RLN within interneurons, resulting in decreased numbers of $\mathrm{PV}^{+}$and SST/RLN-interneurons in the mature cerebral cortex. Indeed, a previous study using our hypoxia model reported gene expression changes in cortex and hippocampus parts, $20 \mu \mathrm{m}$.
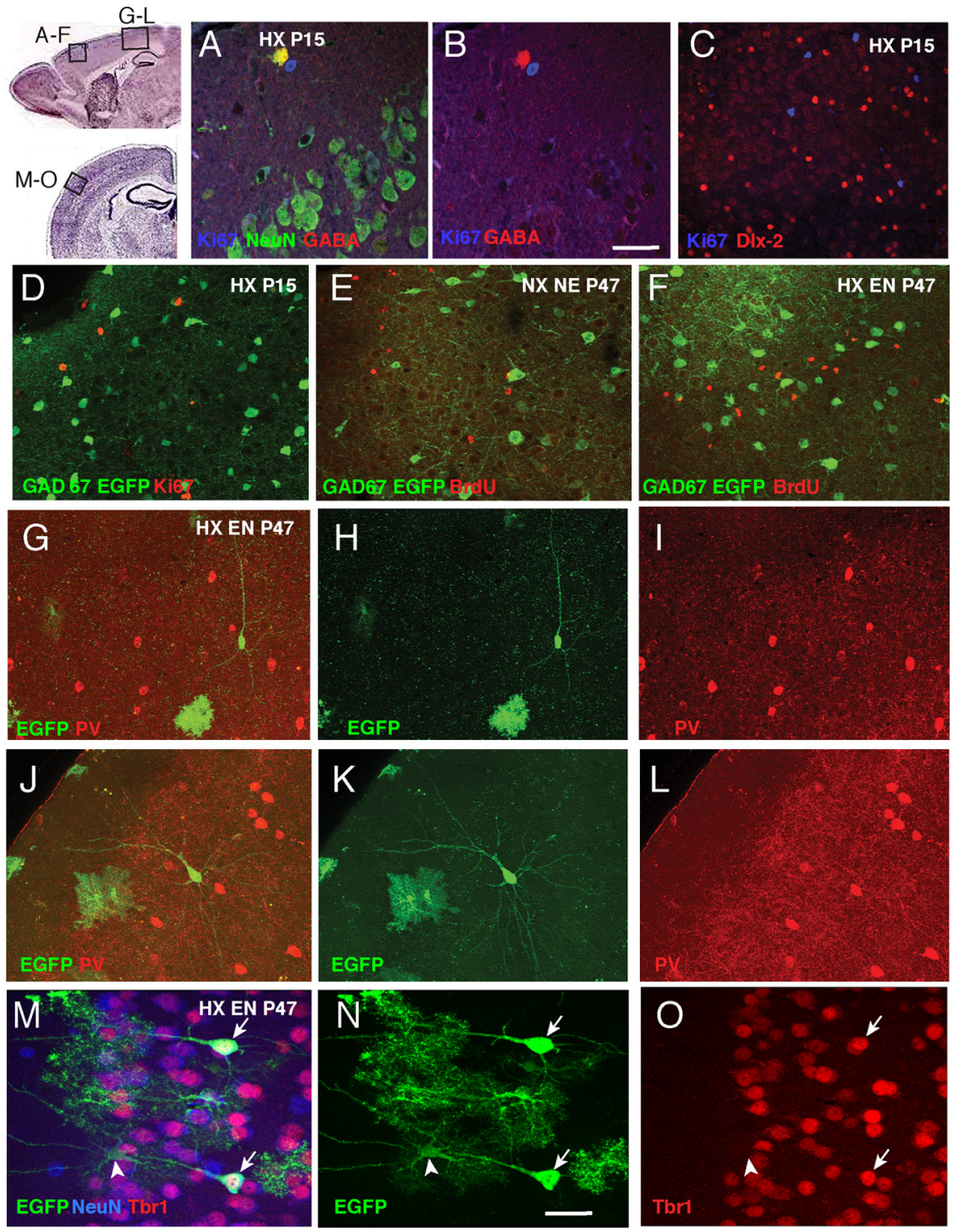

Figure 6. Assessment of cell proliferation and neurogenesis in cortex. Boxed areas on a sagittal and coronal cresyl violet-stained section depict where the images were taken. $\boldsymbol{A}$, Costaining of P15 cortex from hypoxic (HX)-reared mice with Ki67 (blue), GABA (red), and NeuN (green) showing a Ki67 ${ }^{+}$cell next to a $\mathrm{GABA}^{+} \mathrm{NeuN}^{+}$double-labeled cell (yellow when colocalized). $\boldsymbol{B}$, Same staining with the NeuN channel extinguished, showing the GABA-positive cell (red) next to and distinct from the Ki67-positive cell (red). C, D, Immunolabeling of P15 cortex from HX-reared mice with Ki67 (blue) and Dlx-2 (red; C), and GAD67-EGFP (green) and Ki67 (red; $\boldsymbol{D}$ showing lack of proliferation in interneuron lineage cells. $\boldsymbol{E}, \boldsymbol{F}$, GAD67-EGFP (green) and BrdU (red) colabeling of P47 cortex from normoxic nonenriched (NXNE; $\boldsymbol{E}$ ) and hypoxic-reared enriched mice (HXEN; $\boldsymbol{F}$ ) showing lack of interneuron generation. $\mathbf{G}-\mathbf{L}$, Immunolabeling of P47 cortex with EGFP (green) and PV (red) in P47 cortical sections from GCE mice, in which GFAP ${ }^{+}$cells had been permanently tagged with reporter by administering tamoxifen at P12-P14. Note EGFP reporter ${ }^{+}$cells with neuronal morphology that lack PV expression and the presence of EGFP reporter ${ }^{+}$bushy morphology typical of astroglia. $\boldsymbol{M} \mathbf{- 0}$, Immunolabeling of P47 cortex with EGFP (green), Tbr1 (red), and NeuN (blue) in P47 cortical sections from GCE mice, showing genesis of $\mathrm{Tbr} 1+$ neurons from GFAP ${ }^{+}$cells (arrows). Arrowheads point to astrocytes. Scale bars: $\boldsymbol{A}, \mathbf{B}, \mathbf{M}-\mathbf{0}, 10 \mu \mathrm{m}$; in all other

consistent with disrupted synaptic maturation after hypoxia (Curristin et al., 2002). Using GAD67-EGFP transgenic mice in which the EGFP reporter labels GABA interneurons since embryogenesis, regardless of gad 1 mRNA levels, we show that hypoxia did not cause a loss of interneurons, as total GAD67-EGFP ${ }^{+}$cell number was unchanged by hypoxic rearing and there was no activation of caspase- 3 in these cells. Furthermore, hypoxia neither changed the number of Dlx2 ${ }^{+}$GABAergic progenitors in the cortex, nor caused their death. Immunolabeling intensity measurements directly demonstrated decreased PV and SST expression and increased RLN expression in individual cortical interneurons. 
Environmental enrichment restored PV and SST expression but increased neither GAD67-EGFP ${ }^{+}$postmitotic GABA neurons nor Dlx-2 ${ }^{+}$GABA precursors, suggesting that enrichment did not cause an overall increase in GABAergic cells or their progenitors, but rather normalized the expression of mature interneuron markers. However, it is possible that low-grade generation of GABAergic neurons might take place from a Dlx-2negative glial source. For example, we recently demonstrated that postnatal GFAP ${ }^{+}$cells generate cortical excitatory neurons (Bi et al., 2011) and that $\mathrm{GFAP}^{+}$cells generate GABAergic interneurons, including $\mathrm{PV}^{+}$cells, in the early postnatal cerebellum (Silbereis et al., 2009). Thus, we examined whether GFAP ${ }^{+}$cells were able to generate new GABAergic neurons in response to environmental enrichment. After 2 weeks of enrichment, we found putative $\mathrm{GFAP}^{+}$cell-derived interneurons. However they were very rare and appeared quite immature. After a total of 4 weeks in enriched environment, we did not find any astroglia-derived inhibitory interneurons, suggesting that these cells do not survive into maturity.

A retroviral fate-mapping study previously demonstrated that there was an increase in proliferating cells expressing GAD67 in cortical layer 1 after a hypoxic ischemic insult in adult rats, and that these cells generated GABAergic interneurons, but not $\mathrm{PV}^{+}$ cells (Ohira et al., 2010). However, we did not see any colabeling of Ki67 with GABA or GAD67-EGFP reporter in early postnatal mice irrespectively of hypoxic rearing, nor did we observe any appreciable levels of Ki67 expression in Dlx- $2^{+}$cells. Moreover, based on our BrdU fate-mapping experiments, we failed to see any generation of inhibitory interneurons in the cortex at later time points after hypoxia regardless of enrichment status. We did find newborn BrdU-labeled interneurons in normoxic enriched mice. These cells were, however, rare and unlikely to account for the increase in $\mathrm{PV}^{+}$cells found in normoxic, enriched mice. Together, these data led us to conclude that generation of new interneurons is not the reason for the partial recovery of interneuron marker expression after early postnatal hypoxia or the full recovery achieved through environmental enrichment.

The regional effect of variations in oxygen level on inhibitory interneurons has been examined in various models. Decreases in GABA, GAD65/67, and PV-immunoreactive cells, mostly transient, have been reported in the hippocampus in perinatal rat anoxia models (Dell'Anna et al., 1996; Wang et al., 2011) and in the cortex in a prenatal hypoxia model (Louzoun-Kaplan et al., 2008 ) as well as in a perinatal hypoxia-ischemia model (Failor et al., 2010). Our findings are consistent with these studies. In addition, we found that chronic postnatal hypoxia elicited a persistent decrease in SST immunoreactivity and an increase in RLN immunoreactivity within inhibitory cortical neurons in adulthood. RLN is an extracellular matrix protein that regulates cell migration and is secreted by Cajal-Retzius cells during brain development (Caviness and Sidman, 1973; Zhao and Frotscher, 2010). However, in the postnatal brain, RLN is primarily produced by GABAergic interneurons (Ramos-Moreno et al., 2006) and is believed to be involved in synaptic function possibly through modulation of the actin cytoskeleton (Herz and Chen, 2006). It remains to be tested whether the generally increased RLN expression we measured in the cortex of hypoxic-reared mice might have adaptive or maladaptive functions in modulating synaptic plasticity and interneuron function.

Perturbed interneuron differentiation and thus decreased GABAergic signaling in postnatal development could have detrimental effects on cortical function and lasting repercussions for behavior. At birth, all interneuron populations have been formed, have migrated from the ganglionic eminences, and have largely incorporated into the cortex (Batista-Brito and Fishell, 2009). However, early postnatal neocortical connectivity is still immature and undergoes a pronounced process of network organization. During embryonic brain development and in the early postnatal period GABA acts as an excitatory neurotransmitter and becomes inhibitory only later (Ben-Ari, 2002). The expression of $\mathrm{PV}$, a calcium-binding protein that modulates intracellular $\mathrm{Ca}^{2+}$ transients in fast-spiking GABAergic cells (Caillard et al., 2000; Collin et al., 2005), correlates with the functional maturation of fast-spiking GABAergic interneurons (Plotkin et al., 2005). The maturation of $\mathrm{PV}^{+}$inhibitory neurons, and GABA neurons in general, causes the termination of the critical period of synaptic plasticity, which is the period when the cortical synaptic network can be reorganized in response to differences in sensory inputs (Hensch et al., 1998; Hensch and Stryker, 2004). The delays in PV and SST interneuron maturation caused by hypoxia may thus confer prolonged and exaggerated plasticity to the cerebral cortex, an intriguing hypothesis since neuroimaging data suggest that preterm subjects engage alternative pathways for language processing (Myers et al., 2010; Scheinost et al., 2012). In adulthood, $\mathrm{PV}^{+}$and $\mathrm{SST}^{+}$interneurons form a dense inhibitory network of synapses onto adjacent pyramidal cells (Fino and Yuste, 2011; Packer and Yuste, 2011) and are key players in the regulation of cortical excitability. The firing of $\mathrm{PV}^{+}$ neurons generates gamma oscillations, which improve the efficiency of cortical processing and are disrupted in several neuropsychiatric disorders (Bartos et al., 2007; Cardin et al., 2009; Sohal et al., 2009). In mice, decreased numbers of $\mathrm{PV}^{+}$interneurons correlate with the degree of deficit in spatial memory in the Morris water maze task (Stevens et al., 2012). Hence, the lasting decrease in PV and SST expression and therefore dampened inhibitory neurotransmission may be responsible for the increased hyperactivity and deficits in learning and spatial memory observed after hypoxic insults (Chahboune et al., 2009; Li et al., 2009). Conversely, the behavioral improvement observed after environmental enrichment (Salmaso et al., 2012) might in part be mediated by normalization of interneuron neurochemical properties. Indeed, we found that enriched environment completely reversed the hypoxia-induced decrease in PV and SST expression in cerebral cortex. Enriched housing conditions in adulthood were previously found to influence $\mathrm{PV}^{+}$cell numbers in the hippocampus and cortex, in one case decreasing $\mathrm{PV}^{+}$cells in rats that had undergone neonatal anoxia (Iuvone et al., 1996), and, in another case, increasing the number of $\mathrm{PV}^{+}$cells in perilesional cortex of an adult rat stroke model (Inácio et al., 2011). Conversely, social isolation in rats was shown to decrease the number of $\mathrm{PV}^{+}$interneurons in the hippocampus (Harte et al., 2007) and PV expression in prefrontal cortex (Schiavone et al., 2009). Early postnatal environmental enrichment has been shown to increase GABAergic neurotransmission and developmental synaptic maturation (He et al., 2010). However it is not known whether enrichment increases GABA neurotransmission by inducing PV and SST expression, as shown here, or whether it affects other basic properties of interneurons.

PV and SST expression is contingent upon excitatory neuronal input and neurotrophin signaling (Patz et al., 2004; Close et al., 2012; Denaxa et al., 2012). Treatment with the NMDA receptor antagonist ketamine results in decreased PV immunoreactivity with maintained interneuron numbers (Behrens et al., 2007; Powell et al., 2012). Whether hypoxia acts to directly influence interneurons or indirectly affect their maturation by first negatively affecting excitatory neurons (Fagel et al., 2006, 2009) re- 
mains to be shown. It also remains to be determined whether enriched environment acts to increase PV and SST expression by increasing excitatory drive or secretion of neurotrophic factors, or both.

\section{References}

Bartos M, Vida I, Jonas P (2007) Synaptic mechanisms of synchronized gamma oscillations in inhibitory interneuron networks. Nat Rev Neurosci 8:45-56. CrossRef Medline

Batista-Brito R, Fishell G (2009) The developmental integration of cortical interneurons into a functional network. Curr Top Dev Biol 87:81-118. CrossRef Medline

Behrens MM, Ali SS, Dao DN, Lucero J, Shekhtman G, Quick KL, Dugan LL (2007) Ketamine-induced loss of phenotype of fast-spiking interneurons is mediated by NADPH-oxidase. Science 318:1645-1647. CrossRef Medline

Ben-Ari Y (2002) Excitatory actions of GABA during development: the nature of the nurture. Nat Rev Neurosci 3:728-739. CrossRef Medline

Bi B, Salmaso N, Komitova M, Simonini MV, Silbereis J, Cheng E, Kim J, Luft S, Ment LR, Horvath TL, Schwartz ML, Vaccarino FM (2011) Cortical glial fibrillary acidic protein-positive cells generate neurons after perinatal hypoxic injury. J Neurosci 31:9205-9221. CrossRef Medline

Brenner M, Kisseberth WC, Su Y, Besnard F, Messing A (1994) GFAP promoter directs astrocyte-specific expression in transgenic mice. J Neurosci 14:1030-1037. Medline

Bulfone A, Kim HJ, Puelles L, Porteus MH, Grippo JF, Rubenstein JL (1993) The mouse Dlx-2 (Tes-1) gene is expressed in spatially restricted domains of the forebrain, face and limbs in midgestation mouse embryos [published erratum appears in Mech Dev 1993 Aug;42:187]. Mech Dev 40: 129-140. CrossRef Medline

Caillard O, Moreno H, Schwaller B, Llano I, Celio MR, Marty A (2000) Role of the calcium-binding protein parvalbumin in short-term synaptic plasticity. Proc Natl Acad Sci U S A 97:13372-13377. CrossRef Medline

Cardin JA, Carlén M, Meletis K, Knoblich U, Zhang F, Deisseroth K, Tsai LH, Moore CI (2009) Driving fast-spiking cells induces gamma rhythm and controls sensory responses. Nature 459:663-667. CrossRef Medline

Caviness VS Jr, Sidman RL (1973) Time of origin or corresponding cell classes in the cerebral cortex of normal and reeler mutant mice: an autoradiographic analysis. J Comp Neurol 148:141-151. CrossRef Medline

Chahboune H, Ment LR, Stewart WB, Rothman DL, Vaccarino FM, Hyder F, Schwartz ML (2009) Hypoxic injury during neonatal development in murine brain: correlation between in vivo DTI findings and behavioral assessment. Cereb Cortex 19:2891-2901. CrossRef Medline

Close J, Xu H, De Marco García N, Batista-Brito R, Rossignol E, Rudy B, Fishell G (2012) Satb1 is an activity-modulated transcription factor required for the terminal differentiation and connectivity of medial ganglionic eminence-derived cortical interneurons. J Neurosci 32:1769017705. CrossRef Medline

Collin T, Chat M, Lucas MG, Moreno H, Racay P, Schwaller B, Marty A, Llano I (2005) Developmental changes in parvalbumin regulate presynaptic $\mathrm{Ca} 2+$ signaling. J Neurosci 25:96-107. CrossRef Medline

Curristin SM, Cao A, Stewart WB, Zhang H, Madri JA, Morrow JS, Ment LR (2002) Disrupted synaptic development in the hypoxic newborn brain. Proc Natl Acad Sci U S A 99:15729-15734. CrossRef Medline

Deguchi K, Inoue K, Avila WE, Lopez-Terrada D, Antalffy BA, Quattrocchi CC, Sheldon M, Mikoshiba K, D’Arcangelo G, Armstrong DL (2003) Reelin and disabled-1 expression in developing and mature human cortical neurons. J Neuropathol Exp Neurol 62:676-684. Medline

del Río JA, de Lecea L, Ferrer I, Soriano E (1994) The development of parvalbumin-immunoreactivity in the neocortex of the mouse. Brain Res Dev Brain Res 81:247-259. CrossRef Medline

de Lecea L, del Río JA, Soriano E (1995) Developmental expression of parvalbumin mRNA in the cerebral cortex and hippocampus of the rat. Brain Res Mol Brain Res 32:1-13. CrossRef Medline

Dell'Anna E, Geloso MC, Magarelli M, Molinari M (1996) Development of GABA and calcium binding proteins immunoreactivity in the rat hippocampus following neonatal anoxia. Neurosci Lett 211:93-96. CrossRef Medline

Denaxa M, Kalaitzidou M, Garefalaki A, Achimastou A, Lasrado R, Maes T, Pachnis V (2012) Maturation-promoting activity of SATB1 in MGEderived cortical interneurons. Cell Rep 2:1351-1362. CrossRef Medline

Durkin TA, Anderson GM, Cohen DJ (1988) High-performance liquid chromatographic analysis of neurotransmitter amino acids in brain. J Chromatogr 428:9-15. Medline

Fagel DM, Ganat Y, Silbereis J, Ebbitt T, Stewart W, Zhang H, Ment LR, Vaccarino FM (2006) Cortical neurogenesis enhanced by chronic perinatal hypoxia. Exp Neurol 199:77-91. CrossRef Medline

Fagel DM, Ganat Y, Cheng E, Silbereis J, Ohkubo Y, Ment LR, Vaccarino FM (2009) Fgfrl is required for cortical regeneration and repair after perinatal hypoxia. J Neurosci 29:1202-1211. CrossRef Medline

Failor S, Nguyen V, Darcy DP, Cang J, Wendland MF, Stryker MP, McQuillen PS (2010) Neonatal cerebral hypoxia-ischemia impairs plasticity in rat visual cortex. J Neurosci 30:81-92. CrossRef Medline

Fino E, Yuste R (2011) Dense inhibitory connectivity in neocortex. Neuron 69:1188-1203. CrossRef Medline

Freichel C, Potschka H, Ebert U, Brandt C, Löscher W (2006) Acute changes in the neuronal expression of GABA and glutamate decarboxylase isoforms in the rat piriform cortex following status epilepticus. Neuroscience 141:2177-2194. Medline

Ganat YM, Silbereis J, Cave C, Ngu H, Anderson GM, Ohkubo Y, Ment LR, Vaccarino FM (2006) Early postnatal astroglial cells produce multilineage precursors and neural stem cells in vivo. J Neurosci 26:8609-8621. CrossRef Medline

Gelman DM, Marín O (2010) Generation of interneuron diversity in the mouse cerebral cortex. Eur J Neurosci 31:2136-2141. CrossRef Medline

Harte MK, Powell SB, Swerdlow NR, Geyer MA, Reynolds GP (2007) Deficits in parvalbumin and calbindin immunoreactive cells in the hippocampus of isolation reared rats. J Neural Transm 114:893-898. CrossRef Medline

He S, Ma J, Liu N, Yu X (2010) Early enriched environment promotes neonatal GABAergic neurotransmission and accelerates synapse maturation. J Neurosci 30:7910-7916. CrossRef Medline

Hensch TK, Stryker MP (2004) Columnar architecture sculpted by GABA circuits in developing cat visual cortex. Science 303:1678-1681. CrossRef Medline

Hensch TK, Fagiolini M, Mataga N, Stryker MP, Baekkeskov S, Kash SF (1998) Local GABA circuit control of experience-dependent plasticity in developing visual cortex. Science 282:1504-1508. CrossRef Medline

Herz J, Chen Y (2006) Reelin, lipoprotein receptors and synaptic plasticity. Nat Rev Neurosci 7:850-859. CrossRef Medline

Huang HS, Akbarian S (2007) GAD1 mRNA expression and DNA methylation in prefrontal cortex of subjects with schizophrenia. PLoS One 2:e809. CrossRef Medline

Inácio AR, Ruscher K, Wieloch T (2011) Enriched environment downregulates macrophage migration inhibitory factor and increases parvalbumin in the brain following experimental stroke. Neurobiol Dis 41:270-278. CrossRef Medline

Iuvone L, Geloso MC, Dell'Anna E (1996) Changes in open field behavior, spatial memory, and hippocampal parvalbumin immunoreactivity following enrichment in rats exposed to neonatal anoxia. Exp Neurol 139: 25-33. CrossRef Medline

Jiao Y, Zhang C, Yanagawa Y, Sun QQ (2006) Major effects of sensory experiences on the neocortical inhibitory circuits. J Neurosci 26:8691-8701. CrossRef Medline

Li Q, Liu J, Michaud M, Schwartz ML, Madri JA (2009) Strain differences in behavioral and cellular responses to perinatal hypoxia and relationships to neural stem cell survival and self-renewal: modeling the neurovascular niche. Am J Pathol 175:2133-2146. CrossRef Medline

Louzoun-Kaplan V, Zuckerman M, Perez-Polo JR, Golan HM (2008) Prenatal hypoxia down regulates the GABA pathway in newborn mice cerebral cortex; partial protection by MgSO4. Int J Dev Neurosci 26:77-85. CrossRef Medline

Myers EH, Hampson M, Vohr B, Lacadie C, Frost SJ, Pugh KR, Katz KH, Schneider KC, Makuch RW, Constable RT, Ment LR (2010) Functional connectivity to a right hemisphere language center in prematurely born adolescents. Neuroimage 51:1445-1452. CrossRef Medline

Nakamura T, Colbert MC, Robbins J (2006) Neural crest cells retain multipotential characteristics in the developing valves and label the cardiac conduction system. Circ Res 98:1547-1554. CrossRef Medline

Nithianantharajah J, Hannan AJ (2006) Enriched environments, experiencedependent plasticity and disorders of the nervous system. Nat Rev Neurosci 7:697-709. CrossRef Medline

Ohira K, Furuta T, Hioki H, Nakamura KC, Kuramoto E, Tanaka Y, Funatsu N, Shimizu K, Oishi T, Hayashi M, Miyakawa T, Kaneko T, Nakamura S 
(2010) Ischemia-induced neurogenesis of neocortical layer 1 progenitor cells. Nat Neurosci 13:173-179. CrossRef Medline

Onteniente B, Tago H, Kimura H, Maeda T (1986) Distribution of gammaaminobutyric acid-immunoreactive neurons in the septal region of the rat brain. J Comp Neurol 248:422-430. CrossRef Medline

Packer AM, Yuste R (2011) Dense, unspecific connectivity of neocortical parvalbumin-positive interneurons: a canonical microcircuit for inhibition? J Neurosci 31:13260-13271. CrossRef Medline

Patz S, Grabert J, Gorba T, Wirth MJ, Wahle P (2004) Parvalbumin expression in visual cortical interneurons depends on neuronal activity and TrkB ligands during an Early period of postnatal development. Cereb Cortex 14:342-351. CrossRef Medline

Plotkin JL, Wu N, Chesselet MF, Levine MS (2005) Functional and molecular development of striatal fast-spiking GABAergic interneurons and their cortical inputs. Eur J Neurosci 22:1097-1108. CrossRef Medline

Powell SB, Sejnowski TJ, Behrens MM (2012) Behavioral and neurochemical consequences of cortical oxidative stress on parvalbumin-interneuron maturation in rodent models of schizophrenia. Neuropharmacology 62: 1322-1331. Medline

Ramos-Moreno T, Galazo MJ, Porrero C, Martínez-Cerdeño V, Clascá F (2006) Extracellular matrix molecules and synaptic plasticity: immunomapping of intracellular and secreted Reelin in the adult rat brain. Eur J Neurosci 23:401-422. CrossRef Medline

Rudy B, Fishell G, Lee S, Hjerling-Leffler J (2011) Three groups of interneurons account for nearly $100 \%$ of neocortical GABAergic neurons. Dev Neurobiol 71:45-61. Medline

Salmaso N, Silbereis J, Komitova M, Mitchell P, Chapman K, Ment LR, Schwartz ML, Vaccarino FM (2012) Environmental enrichment increases the GFAP + stem cell pool and reverses hypoxia-induced cognitive deficits in juvenile mice. J Neurosci 32:8930-8939. CrossRef Medline

Scafidi J, Fagel DM, Ment LR, Vaccarino FM (2009) Modeling premature brain injury and recovery. Int J Dev Neurosci 27:863-871. CrossRef Medline

Scheinost D, Benjamin J, Lacadie CM, Vohr B, Schneider KC, Ment LR, Papademetris X, Constable RT (2012) The intrinsic connectivity distribution: a novel contrast measure reflecting voxel level functional connectivity. Neuroimage 62:1510-1519. CrossRef Medline
Schiavone S, Sorce S, Dubois-Dauphin M, Jaquet V, Colaianna M, Zotti M, Cuomo V, Trabace L, Krause KH (2009) Involvement of NOX2 in the development of behavioral and pathologic alterations in isolated rats. Biol Psychiatry 66:384-392. CrossRef Medline

Schwartz ML, Vaccarino F, Chacon M, Yan WL, Ment LR, Stewart WB (2004) Chronic neonatal hypoxia leads to long term decreases in the volume and cell number of the rat cerebral cortex. Semin Perinatol 28: 379-388. CrossRef Medline

Silbereis J, Cheng E, Ganat YM, Ment LR, Vaccarino FM (2009) Precursors with glial fibrillary acidic protein promoter activity transiently generate GABA interneurons in the postnatal cerebellum. Stem Cells 27:1152-1163. CrossRef Medline

Sohal VS, Zhang F, Yizhar O, Deisseroth K (2009) Parvalbumin neurons and gamma rhythms enhance cortical circuit performance. Nature 459: 698-702. CrossRef Medline

Soriano P (1999) Generalized lacZ expression with the ROSA26 Cre reporter strain. Nat Genet 21:70-71. CrossRef Medline

Stevens HE, Jiang GY, Schwartz ML, Vaccarino FM (2012) Learning and memory depend on fibroblast growth factor receptor 2 functioning in hippocampus. Biol Psychiatry 71:1090-1098. CrossRef Medline

Sugiyama S, Di Nardo AA, Aizawa S, Matsuo I, Volovitch M, Prochiantz A, Hensch TK (2008) Experience-dependent transfer of Otx2 homeoprotein into the visual cortex activates postnatal plasticity. Cell 134:508-520. CrossRef Medline

Tamamaki N, Yanagawa Y, Tomioka R, Miyazaki J, Obata K, Kaneko T (2003) Green fluorescent protein expression and colocalization with calretinin, parvalbumin, and somatostatin in the GAD67-GFP knock-in mouse. J Comp Neurol 467:60-79. CrossRef Medline

Wang Y, Zhan L, Zeng W, Li K, Sun W, Xu ZC, XuE (2011) Downregulation of hippocampal GABA after hypoxia-induced seizures in neonatal rats. Neurochem Res 36:2409-2416. CrossRef Medline

Wonders CP, Anderson SA (2006) The origin and specification of cortical interneurons. Nat Rev Neurosci 7:687-696. CrossRef Medline

Zhao S, Frotscher M (2010) Go or stop? Divergent roles of Reelin in radial neuronal migration. Neuroscientist 16:421-434. CrossRef Medline 